\title{
Poverty and Decentralisation
}

\section{in Kutai Barat}

The Impacts of Regional Autonomy on Dayak Benuaq Wellbeing

\section{R e s e a r c h $R$ e $p$ o r t}

Making Local Government More Responsive to the Poor: Developing Indicators and Tools to Support Sustainable Livelihood under Decentralization

Michaela Haug 



\section{Poverty and Decentralisation in Kutai Barat}

The Impacts of Regional Autonomy on

Dayak Benuaq Wellbeing

Making Local Government More Responsive to the Poor: Developing Indicators and Tools to Support Sustainable Livelihood under Decentralization

Res e a r h R e port

Michaela Haug 
(C) Copyright 2007 CIFOR.

All rights reserved. No part of this publication may be reproduced, stored in a retrieval system, or transmitted, in any form or by any means (electronic, mechanical, photocopying, recording or otherwise) without the prior permission of the publishers.

ISBN 978-979-1421-40-7

$48 \mathrm{p}$.

Michaela Haug

Making Local Government More Responsive to the Poor: Developing Indicators and Tools to Support Sustainable Livelihood under Decentralization. Poverty and Decentralisation in Kutai Barat: The Impacts of Regional Autonomy on Dayak Benuaq Wellbeing Research Report. Bogor, Indonesia: CIFOR, 2007.

Photos by Michaela Haug

Published by Center for International Forestry Research

Jl. CIFOR, Situ Gede, Sindang Barang,

Bogor Barat 16115, Indonesia

Tel.: +62 (251) 622622; Fax: +62 (251) 622100

E-mail: cifor@cgiar.org

Web site: http://www.cifor.cgiar.org 


\section{Contents}

Abbreviations, Acronyms and Glossary iv

Acknowledgements vi

Executive Summary vii

1. Introduction 1

1.1. Research Objectives 1

1.2. Theoretical Framework 4

1.3. Research Methods 5

2. Regional Frame $\quad 7$

2.1. Research Location 7

2.2. The Dayak Benuaq 11

3. Case Studies 13

3.1. Poverty Perception of the Dayak Benuaq 13

3.2. Changes and their Causal Relations 21

3.3. Common and Different Trends 33

3.4. Most Recent Changes 35

4. Conclusions 38

5. Recommendations 41

Endnotes 44

References $\quad 45$ 


\section{Abbreviations, Acronyms and Glossary}

\author{
adat \\ Askes Gakin \\ B.B. \\ BIOMA \\ BKKBN \\ BKM \\ BKPS-BBM
}

$\mathrm{BMZ}$

BPK

BPS

BTL

CARE Indonesia

CIFOR

CSF

DINAS Kehutanan

DINAS Kesehatan

DINAS Pendidikan

DPM

e.g.

emic

etc.

GDP

GN-OTA

gotong-royong

GSM

HDI

$\mathrm{HPH}$

$\mathrm{HPHH}$

HPI

i.e.

IPPK

IUPHHK

JPS

kabupaten

Kehati

$\mathrm{kk}$

$\mathrm{km}$ customs, including traditional laws; customary (adjectival)

Asuransi Kesehatan Keluarga Miskin (health insurance for poor people)

Bahasa Benuaq (Benuaq language)

Yayasan Biosfer Manusia (local NGO)

Badan Koordinasi Keluarga Berencana Nasional (National Family Planning

Coordination Agency)

Bantuan Khusus Murid (special support for pupils)

Bantuan Kompensasi Pengurangan Subsidi-Bahan Bakar Minyak (Compensation aid for the reduced fuel subsidies)

Bundesministerium für wirtschaftliche Zusammenarbeit und Entwicklung (Federal Ministry for Economic Cooperation and Development, Germany)

Badan Perwakilan Kampung (community councils)

Badan Pusat Statistik (Central Statistics Agency)

Bantuan Tunai Langsung (direct cash support, part of BKPS-BBM)

Indonesian country office of CARE International

Center for International Forestry Research

Center for Social Forestry

Forestry Service

Health Service

Education Service

Dinas Pemerdayaan Masyarakat (Community Empowerment Service)

for example

cultural specific perception

et cetera (and so on)

Gross Domestic Product

Gerakan National Orang Tua Asuh (National Movement of Foster Parents)

Collective action

Gerakan Sendawar Makmur (Prosperous Sendawar Movement)

Human Development Index (UNDP)

Hak Pengusahaan Hutan (Commercial Forestry Concession)

Hak Pemungutan Hasil Hutan (Forest Product Harvest Concession)

Human Poverty Index (UNDP)

that is

Ijin Pemungutan dan Pemanfaatan Kayu (Wood Harvesting and Use Permit)

Ijin Usaha Pemanfaatan Hasil Hutan Kayu (Forest Wood Product Utilisation Permit)

Jaring Pengaman Sosial (Social Safety Net)

district

Yayasan Keanekaragaman Hayati Indonesia (Indonesian NGO)

Kepala Keluarga (familiy head)

kilometre(s) 
M.A.

NGO

NESP

No.

OECD

Orde Baru

p.

P2D

p.a.

PhD / Ph.D.

PKPS-BBM

Posyandu

pp.

Prestasi

PT ASKES

PT KEM

Puskesmas

Puti Jaji

Raskin

Reformasi

$\mathrm{Rp}$

SHK

SK

SLA

SLTA

SLTP

SoSek

SUSEDA

SWB

UN

UNDP

US\$

USA

UU

VCD

Yayasan Anum Lio
Master of Arts (postgraduate degree)

nongovernmental organisation

nested spheres of poverty

Number

Organisation for Economic Co-operation and Development

New Order, the era of former President Suharto

page

Program Pengembangan Prasarana Perdesaan (Infrastructure Development

Programme)

per annum (per year)

Doctor of Philosophy (doctorate degree)

Program Kompensasi Pengurangan Subsidi Bahan Bakar Minyak (Programme on Compensation for Reduced Petroleum Fuel Subsidies)

Pos Pelayanan Keluarga Berencana - Kesehatan Terpadu (Family Planning Service Office)

pages

Excellent school performance

PT Asuransi Kesehatan Indonesia (Indonesian Health Insurance Company)

PT Kelian Equatorial Mining

Pusat Kesehatan Masyarakat (local health centre, small clinic)

local NGO

Beras Miskin (subsidised rice for the poor)

Reform period following the downfall of former President Suharto

Indonesian rupiah

Yayasan Sistem Hutan Kerakyatan (Community Forest Foundation, NGO active in Kutai Barat)

Surat Keputusan (decree)

Sustainable Livelihood Approach

Sekolah Lanjutan Tingkat Atas (senior high school)

Sekolah Lanjutan Tingkat Pertama (junior high school)

Social-economics Division

Survey Sosial Ekonomi Daerah (Local Socioeconomic Survey)

subjective wellbeing

United Nations

United Nations Development Programme

US dollar

United States of America

Undang-undang (national Law)

Video Compact Disk

former Rio Tinto Foundation (local NGO) 


\section{Acknowledgements}

This report summarises the major insights of my $\mathrm{PhD}$ research, which formed an integral part of the CIFOR-BMZ Poverty and Decentralization Project Making Local Government More Responsive to the Poor: Developing Indicators and Tools to Support Sustainable Livelihood under Decentralization. My research was financed by the CIFOR-BMZ project and made possible through the close cooperation among the District Government of Kutai Barat, the CIFOR-BMZ Project Team, Freiburg University and many supportive people in Kutai Barat.

First of all I want to thank Stefan Seitz and Michel Becker for supervising my forthcoming $\mathrm{PhD}$ thesis.

In Indonesia, I want to thank the District Government of Kutai Barat. In particular, Rama A. Asia, Encik Mugnidin, Fredrick Ellia, Paulus Matius, Silas Sinan and Yuvinus Nyintih. I also want to thank Agung Sarjono and the members of the Center for Social Forestry at Mularwarman University in Samarinda, the members of Puti Jaji, BIOMA and SHK, as well as Oliver Venz, Cathrin Bullinger, Brigita Edna, Richard Payne and Benjamin for many insightful discussions. Further, I want to thank all people of Engkuni Pasek, Jontai and Muara Nayan for their cordiality and patience. Representative of the many people that supported my fieldwork, I want to thank here Itaq David and Kakah David, Itaq Nelly and Kakah Nelly, Tinen Nelly and Taman Nelly, and Tinen Sur and Taman Sur. Living in my research villages was a joyful experience, as I was well received and patiently supported by the people in all three research locations.

At CIFOR, I wish to thank the entire Poverty and Decentralization Project Team, including Lini Wollenberg, Moira Moeliono, Godwin Limberg, Ramses Iwan, Wil de Jong, Peter Cronkelton, Kristen Evans, Rolando Haches, Dante Fuentes, Marco Antonio Albornoz and especially Christian Gönner and Ade Cahyat for great teamwork, most valuable guidance and encouragement throughout my research. At CIFOR, I further thank Rita Rahmawati, Dina Hubudin, Charlotte Soeria, Sonya Dewi, Atie Puntodewo and Yuan Oktafian. I also thank consultant editor Guy Manners.

And last but not least, I want to thank Sabine and Norbert Haug, Hildegard and Gustav Pribbernow, Ursula Zarth and Bison for their inexhaustible personal support. 
As an integral part of the CIFOR-BMZ project Making Local Government More Responsive to the Poor: Developing Indicators and Tools to Support Sustainable Livelihood under Decentralization, the main objective of my research was to understand the impacts of regional autonomy on the wellbeing of the Dayak Benuaq in Kutai Barat, East Kalimantan, Indonesia. My study provides insights into the Dayak Benuaq's own perception of poverty, documents changes happening after decentralisation, and explains the causal relations behind these ongoing processes.

The Dayak Benuaq have a shared understanding of poverty which is largely based on a household's economic situation. Commonly, people are considered as poor if they experience difficulties in fulfilling basic needs such as food, housing and clothing. Furthermore, the Dayak Benuaq share an emic concept of a good life (bolupm bueq B.B.) and a bad life (bolupm daat B.B.), which comprises a broad variety of economic, social, political, physical and emotional aspects, and seems very similar to the concepts of wellbeing and illbeing.

Decentralisation clearly had some positive impacts on Dayak Benuaq livelihoods. The creation of the new district, Kutai Barat, improved the political participation and selfdetermination of the formerly marginalised Dayak group, as the Benuaq now form the majority of the new district's government. With regional autonomy, infrastructure and government services improved in many areas and new economic opportunities opened up.

However, these improvements and opportunities were not enjoyed by everyone. Official poverty data shows a stagnation of poverty incidence at a higher level than before decentralisation, and research findings indicate that inequality within the villages increased dramatically as a result of uneven distribution of benefits. Local government's poverty alleviation programmes are visible in the villages, but they often fall short of the expectations of both local government officials and villagers, due to poor implementation and weak control mechanisms. The impact of decentralisation was felt most negatively in the natural and social spheres. Conflicts among villagers—but also between villagers and companies-have increased since decentralisation. Most conflicts arise over land and natural resources, which both have increasing value. Many conflicts are further complicated by a growing tendency towards individual ownership and weakening traditional conflict resolution mechanisms. Extractive resource use, such as logging and increased coal mining, in Kutai Barat led to a decline of river water and forest quality. The lax control of timber, mining and oil palm companies through local government further adds to their negative impact on the natural and social environments.

The situation worsened for most households as prices increased sharply after the fuel subsidies stopped in October 2005, and new forest policies drew back authority to central government and intensified the control of illegal logging. The increased material wealth 
was mainly short lived, as only a few families used the temporarily high cash income from the timber sector to secure their livelihoods through long-term investments. By 2006, people were falling back on alternative livelihood strategies, such as increased subsistence production, rattan and rubber. Besides that, many express the hope that after the timber boom they will soon receive fees or compensation payments from the increasing number of coal mines that are opening.

Decentralisation thus generated a variety of new opportunities in Kutai Barat, but with high costs in the social and natural environments. The unbalanced use of new political and economic opportunities and the extractive use of natural resources will ultimately increase the vulnerability of the Dayak Benuaq and put environmental and social sustainability at risk, unless local government takes action. Counter measures should include an improvement of the implementation of poverty alleviation programmes, a long-term development plan based on sustainable resource use, and stricter control of companies in order to minimise their negative impact on the environment and to maximise their benefits for the population. 


\section{Introduction}

Through the implementation of decentralisation reforms, local governments in many countries gained increased political authority and decision-making power, providing them with better opportunities to influence the wellbeing of their constituents. These governments could implement more effective poverty alleviation if they had better tools and more precise methods for prioritising actions and evaluating impacts. The CIFORBMZ research project Making Local Government More Responsive to the Poor: Developing Indicators and Tools to Support Sustainable Livelihood under Decentralization assisted local governments in Indonesia (Kutai Barat and Malinau) and Bolivia (Pando) from 2003 to 2006 to improve the impact of their poverty alleviation policies. The project team applied a participatory learning approach for developing local monitoring and planning tools to measure poverty with locally specific indicators, prioritise actions and evaluate the impacts of local government's poverty alleviation programmes. The team also conducted indepth field research to improve the understanding of trends in local poverty and wellbeing and the impact of decentralisation on local livelihoods.

\subsection{Research Objectives}

As an integral part of the CIFOR-BMZ project, the main objective of my research was to understand the impacts of regional autonomy on the wellbeing of the Dayak Benuaq, and the underlying causes of recent changes in Kutai Barat, East Kalimantan. The study sought to gain insights into the Benuaq's own perceptions of poverty, document ongoing processes of socioeconomic change, and understand their intertwinement with decentralisation.

\section{Analysing the multidimensionality of poverty}

The understanding of poverty has broadened from the mere consideration of income or consumption, to definitions that comprise various economic, political and social dimensions of wellbeing, including aspects like self-determination, choice, assets, capabilities, inclusion, inequality, human rights, entitlement, vulnerability, empowerment and subjective wellbeing. Among the leading international development agencies, this multidimensional nature of poverty has become 'virtually undisputed' (Sumner 2007, p. 4), and anchored in their major publications-e.g., the Millennium Development Goals (UN 2000), the World Development Report (World Bank 2000) and the OECD Development Assistance Committee Poverty Guidelines (OECD 2001).

Despite the broadening concept of poverty and a growing interest in the views of the poor themselves (Narayan et al. 2000a, b), the measurement of poverty remained rather undynamic. International agencies and national governments still favour money-metric poverty lines and economic poverty indicators, as the new concepts are considered as difficult to quantify (Kanbur and Squire 2001; Sumner 2004). This continuing narrow 
measurement neglects the manifold dimensions of poverty and tends to support old, simplistic poverty alleviation strategies that rely solely on macroeconomic growth, income generation, or infrastructural improvements.

Eager to capture the various aspects of poverty, $\mathrm{we}^{1}$ developed a model that can be used as a tool to measure the multidimensionality of poverty with quantifiable indicators as well as a framework for qualitative analysis (Gönner et al. 2007a). Capturing poverty very broadly, one aim of my research was to test our model as a framework for analysing trends in local wellbeing.

\section{Linking poverty and cultural anthropology}

Compared to the great attention that poverty receives within the international development discourse, cultural anthropology has been rather diffident in the recent debates about poverty. This seems odd, as since the beginnings of the discipline cultural anthropologists have studied, lived and worked with people that would commonly be considered poor. Anthropological studies do provide deep insights into poor people's lives, their own perceptions of poverty and specific aspects of poverty (see for example Wikan 1980, 1996; Scott 1985; ScheperHughes 1992; Breman and Wiradi 2002). However, there is a remarkably high reluctance within the discipline to speak of 'poverty', to produce generalisable theoretical concepts and to get actively engaged in policy relevant debates. ${ }^{2}$

The highly critically view that many academic cultural anthropologist hold of development cooperation institutions, their policies and practices (as expressed by Escobar 1991) contributes to this reluctance, but its main reason lies within cultural relativism. Within cultural anthropology, the understanding of poverty has been largely distanced from material aspects and is seen as a social category that has to be viewed relatively. To avoid ethnocentric connotations, cultural anthropologists thus prefer not to speak of poverty (Verne 2005, p. 5).
Although cultural relativism is an important foundation of cultural anthropology, I agree with Verne that too relative a view of poverty makes 'the other' (i.e. those studied) more foreign than they actually are and eclipses the fact that poverty contains manifold universal human experiences of deprivation, and further tends to exclude global coherences which are especially strongly linked to the political, economical, natural and social aspects of poverty (Verne 2005, pp. 5f). Therefore, I support a position of cultural anthropology that contributes more actively to poverty research and policy relevant debates.

In my research, I investigate the emic poverty concept of the Dayak Benuaq and build on the holistic perspective of cultural anthropology to address the multidimensionality of poverty and the complexity of causal relations. Furthermore, I use a multidimensional poverty concept that has been developed by an interdisciplinary team, ${ }^{3}$ showing that cultural anthropology has a lot to offer poverty research, including on conceptual and methodological issues.

\section{Understanding poverty trends in Kutai Barat}

It is difficult to trace the development of poverty in Kutai Barat, as no consistent official poverty data exist. This is mainly due to the fact that poverty has been measured in Kutai Barat by different institutions in different ways. ${ }^{4}$ The Central Statistics Agency (BPS), for example, measures poverty based on consumption, while the National Family Planning Coordination Agency (BKKBN) uses socioeconomic criteria (Cahyat 2004). Additionally, most indicators used for poverty measurement in Indonesia conform to conditions and lifestyle in urban Java and thus are inappropriate to assess poverty in rural, forested areas such as Kutai Barat. Hence, it is not surprising that in 2002, some $12.63 \%$ of the population in Kutai Barat was poor according to BPS, while the figure was $47.3 \%$ according to BKKBN. An additional poverty survey carried out 
to identify households eligible for cash payment to compensate the reduced fuel subsidies (BTL) reported a poverty rate of 39\% in 2005 (Gönner et al. 2007b, p. 9)!

The inconsistency of available poverty data and the unresponsiveness of the methods to local conditions have been the major reasons for developing a new method to monitor household wellbeing in Kutai Barat. The aim of my research was to complement the poverty monitoring conducted by the CIFOR-BMZ project in cooperation with local government. My study should contribute to a better understanding of the specific local conditions and perceptions of poverty, and the complex causal relations lying behind recent poverty trends in Kutai Barat.

\section{Understanding the impacts of decentralisation}

Governments in many countries decentralise fiscal, political and administrative responsibilities to subnational levels of government, hoping to enhance the quality of local administration, improve poverty alleviation and promote sustainable resource management. However, recent studies of decentralisation reforms worldwide show that reality often lags behind the high expectations linked with decentralisation (e.g. Ahmad et al. 1998; Crook and Manor 1998; Agrawal 2000; Crook and Sverrison 2001; Thomi et al. 2001; Brillantes and Cuachon 2002; Ribot 2002; Shackleton et al. 2002).

Indonesia implemented one of the most rigorous decentralisation reforms throughout Asia with Law 22 of 1999, providing district governments with larger shares of local revenues, and Law 25 of 1999 , devolving the full responsibility for education, health, labour, public works, the environment and natural resource management to local governments. In October 2004, the previous decentralisation laws were replaced by Laws 32 and 33 of 2004, which retained regional autonomy but recentralised many fields of authority to higher levels of government, e.g. the forest management sector.
So far, the impacts of decentralisation in Indonesia have varied enormously across the regions (e.g. Benda-Beckmann and Benda-Beckmann 2001; Klinken 2002; Sakai 2002; Aspinall and Fealy 2003). In East Kalimantan, official poverty data show a stagnation of poverty indices at a higher level than before decentralisation (Gönner et al. 2007b). The new authority of local governments over natural resource management enabled districts temporarily to issue small-scale logging licences (called $\mathrm{HPHH}$ or IPPK). However, with the recentralisation of the forest sector in 2004, the authority to issue logging licences again became the exclusive right of central government. Decentralisation has created great uncertainties in East Kalimantan. The small-scale logging licences led mainly to short-lived benefits for local communities, but further increased deforestation (Rhee 2000; Casson 2001; Barr et al. 2001, 2006; Barr and Resosudarmo 2002; Gönner et al. 2007b). The aim of my research was to gain insights into the specific dynamics that decentralisation provoked in Kutai Barat and to understand how and why they influenced Dayak Benuaq livelihoods.

\section{Complementing research on Borneo and the Dayak Benuaq}

During its long history of resource extraction, trade and migration, Borneo has undergone many transitions. The extreme increase of resource exploitation during the last century caused severe environmental degradation and accelerated many processes of social, economic and political change (see, e.g., Cleary and Eaton 1992; Padoch and Peluso 1996). Since decentralisation, East Kalimantan has been undergoing yet another rise of resource exploitation, which is characterised by an increasing intrusion of companies into the interior, invited by local governments eager to raise their local revenues, which will doubtlessly be a trigger for further processes of change. By examining these recent processes and their intertwinement with decentralisation, my study enriches recent 
research on social, economic and political change on Borneo.

Research on the Dayak Benuaq has mainly focused on traditional cultural practices (e.g. Massing 1981, 1982, Bonoh 1982, 1985a, b; Latief 1996/97, 1998; Devung 1990; Hopes 1997; Hopes et al. 1997; Madrah 1997, 2001; Madrah and Karaakng 1997; Oley 1997; Venz 2002; Harris 2006) and resource management (e.g. Sardjono 1990; Nanang 1990; Kraienhorst 1990; Sardjono and Samsoedin 2001; Gönner 2001, 2002; Gönner and Seeland 2002; Haug 2002; Crevello 2003; Matius 2004). In addition, there is a vast body of grey literature comprising NGO material, personal notes, reports of adat meetings and material collected by interested Benuaq themselves. Information about recent economic, social and political processes are mainly found within the grey literature, and some aspects are mentioned in the works of Massing (1986), Haryo Widjono AMZ (1998), Gunawan et al. (1999), Gönner (2001, 2002), and Safitri and Bosko (2002). However, no comprehensive study has so far been devoted to these processes. My research aims to close this gap and contribute to an understanding of recent social, political and economic changes in Benuaq society.

\section{Research Questions}

Based on the objectives outlined, the following research questions lay at the heart of my study:

\section{Empirical questions:}

1. How do the Dayak Benuaq perceive poverty?

2. What processes of change are going on?

3. Which causal relations lie behind these changes?

4. What role does decentralisation play in these processes?

\section{Theoretical/methodological questions:}

1. How can poverty and changes of wellbeing be analysed in a comprehensive manner?

2. How does decentralisation influence poverty?

\subsection{Theoretical Framework}

We understand poverty as a multidimensional phenomenon and accordingly see its opposite not in mere material wealth but in a comprehensive state of wellbeing (Gönner et al. 2007a; Haug forthcoming). The resulting definition of poverty as lack of wellbeing might seem surprisingly simple, but it has proved very useful for assessing local poverty perceptions and for analysing the various dimensions of poverty.

In order to capture the manifold notions and attributes of poverty, we conceptualised a multidimensional concept (Gönner et al. 2007a), which draws on ideas developed in the capability approach of Amartya Sen (e.g. 1993, 1997, 1999) and the sustainable livelihood approach (e.g. Chambers and Conway 1991; Scoones 1998; Baumann 2000; Solesbury and Daniels 2002). Our model—nested spheres of poverty (NESP) analytically ${ }^{5}$ distinguishes between different aspects of wellbeing, which are graphically represented as a series of concentric circles (see Figure 1). The core is formed by subjective wellbeing (SWB) and the basic wellbeing aspects of health, wealth and knowledge, while the context comprises economic, social, natural and political aspects as well as infrastructure and services.

Subjective wellbeing is highly individual and emotional. It does not have a constant value, but varies with moods and circumstances. It is often the outcome of comparing one's current standard of living with that of former times or that of others. Personal feelings of happiness, safety, inclusion and contentedness also contribute to the overall subjective wellbeing.

Wealth, health and knowledge represent what is commonly referred to as 'basic needs'-nutrition, health and housing, as well as education and general individual capabilities. In our model, 'wealth' stands for an adequate minimum possession of material wealth, 'knowledge' comprises formal, informal and traditional knowledge, and 'health' includes 
Figure 1. Nested spheres of poverty.

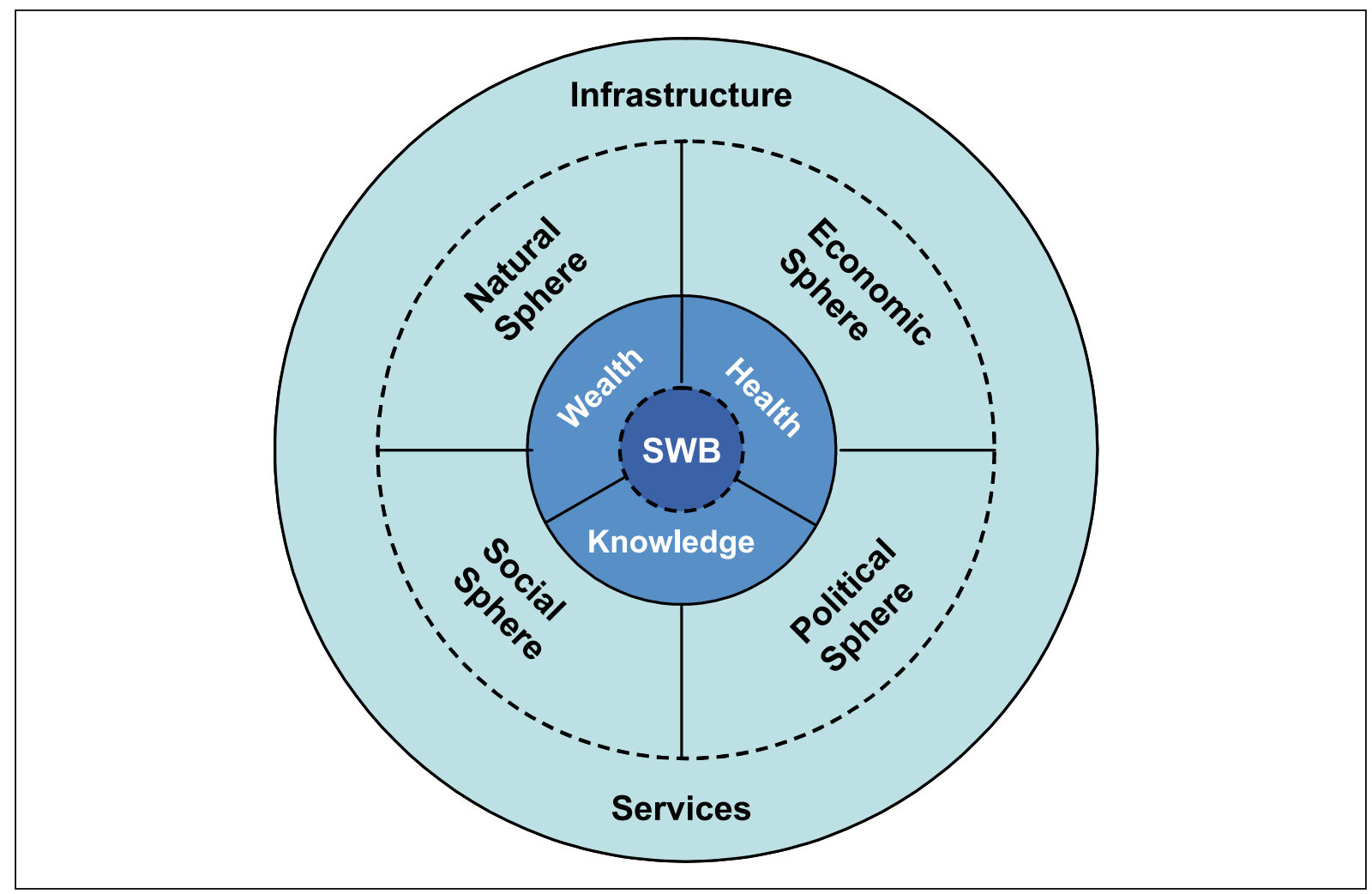

nutritional aspects, the availability of clean drinking water, as well as the individual state of health.

The context consists of five 'spheres'. The natural sphere includes the availability and quality of natural resources. The economic sphere covers economic opportunities and safety nets. Social capital and cohesion, but also trust and conflicts make up the social sphere. The political sphere comprises rights and participation or representation in decision making, empowerment and freedom. The fifth sphere comprises infrastructure and services provided by government agencies, NGOs, development projects or the private sector. It forms the outer layer of the NESP model as infrastructure and services can easily cross into the other spheres.

While we developed quantifiable indicators for each sphere within the project to measure household wellbeing in Kutai Barat, I use the model in my research as an analytical framework to assess changes and trends in wellbeing.

\subsection{Research Methods}

Between 2004 and 2006, I conducted 22 months $^{6}$ of field research in three Dayak Benuaq villages. ${ }^{7} \mathrm{My}$ research methods included participant observation, household surveys, and informal and semistructured interviews with villagers, NGO staff, private sector representatives and local government officials. The research addressed different levels: while perceptions of poverty and wellbeing were assessed on an individual level, livelihood patterns and strategies were studied at the household level. Ongoing processes and dynamics were assessed at village and district levels and, where necessary, followed up to national and international levels.

To gain insights into the emic perceptions of poverty, I started with informal interviews and then refined my understanding further through indepth interviews with key informants. I also conducted a survey with 300 people $^{8}$ to gain comparable information about perceptions of poverty and wellbeing according to age and gender. 
To gain a first insight into recent changes in the villages, I conducted focus group discussions on the impacts of regional autonomy and perceived changes over the previous 5 years. On the basis of these insights from the focus group discussions, I conducted a first household survey with 80 households ${ }^{9}$ in 2004, including demographic data, physiological, material, emotional and cognitive aspects, as well as trends within the natural, economic, social and political contexts. In 2005, I interviewed the households again to capture recent changes following the issuing of the new decentralisation laws in October 2004 and the intensified control of illegal logging.

Besides complementary literature research, regular discussions with key respondents over the central questions of my research played a major role in sharpening and refining my understanding of the ongoing processes. The insights I gained in these conversations form an important foundation for interpreting the data collected in the surveys. Some key informants were chosen because they were especially knowledgeable (e.g. village and adat leaders, NGO and government officials), some because of their personal commitment to topics relevant to the research (e.g. people engaged in village development efforts) and others because of the personal good relationship that I developed with them. To interpret and crosscheck my data, I could additionally also draw on data collected within the CIFOR-BMZ project.

In each village, I lived with a family and gained many interesting insights through the integration into three different Benuaq households. In one of the villages, I lived with two fellow cultural anthropologists, Oliver Venz and Richard Payne, who were both working on ritual aspects of Benuaq culture.

All interviews were conducted by myself in Indonesian, supplemented with some crucial expressions in the Benuaq language (B.B.). Asking people about poverty while being related with a foreign aid project always raises expectations. I tried to meet them with detailed information about my research and the project, trying to provide a realistic estimation of the opportunities afforded by, as well as the limitations of, the CIFOR-BMZ project. 


\section{Regional Frame}

\subsection{Research Location}

The district (kabupaten) of Kutai Barat came into existence in October 1999 and comprises the western part of the former district of Kutai. With its vast remote areas, its rich natural resources, but poor people, Kutai Barat represents a typical district of many forested areas in the tropics. Three areas are distinguished within the district according to their geographical characteristics: upstream areas (ulu riam), lowland areas (daratan rendah), and highland regions (daratan tinggi).

With decentralisation, the budget of local government increased significantly. ${ }^{10}$ Most efforts were put into the erection of the new district government and infrastructure development. However, new economic opportunities and improving transportation have been unevenly distributed among the regions. Many new roads and bridges were constructed around Sendawar, the semiurban centre of the highlands, while the upstream areas are still only accessible by plane (flights subsidised) and seasonally by longboat, and some parts of the lowlands, e.g. Bentian Besar and Long Hubung, are left without any subsidised access.

Kutai Barat is home to many ethnic groups (see Table 1), comprising different Dayak groups, such as the Tunjung (Tonyoi), Benuaq, Bahau, Kenyah and Bentian, Malay-

Table 1. Ethnic majority within household.

\begin{tabular}{|c|c|c|c|c|c|}
\hline $\begin{array}{l}\text { Tunjung } \\
\text { (Tonyoi) }\end{array}$ & $24.2 \%$ & Bugis & $3.2 \%$ & Seputan & $0.6 \%$ \\
\hline Benuaq & $19.9 \%$ & Kenyah & $2.4 \%$ & Batak & $0.2 \%$ \\
\hline Kutai & $15.5 \%$ & Bentian & $2.3 \%$ & Bukat & $0.2 \%$ \\
\hline Jawa & $10.7 \%$ & $\begin{array}{l}\text { Penihing } \\
\text { (Aoheng) }\end{array}$ & $1.7 \%$ & Luangan & $0.2 \%$ \\
\hline Bahau & $9.3 \%$ & Bakumpai & $1.7 \%$ & & \\
\hline Banjar & $4.5 \%$ & Kayan & $1.4 \%$ & & \\
\hline
\end{tabular}

Source: Gönner et al. (2007b).

speaking groups like the Banjar and Kutai, and groups from other Indonesian islands, like Javanese, Bugis and Batak.

With decentralisation, the influence of Dayak groups (especially Benuaq, Tunjung and Bahau) increased and led them out of their previous political marginalisation. With their strengthened position, Dayak culture has been revitalised throughout the district and Dayak identity, even subgroup identity, gained new political and economic importance, as could be witnessed during the campaigns leading up to the district head election in 2006.

My field research in Kutai Barat was conducted in the villages Engkuni Pasek, Jontai and Muara Nayan. They were chosen on the basis of several criteria: they should have a majority population of Dayak Benuaq, be classified as poor villages and have been part of the village baseline survey conducted by the CIFOR-BMZ project team in 2003 (Cahyat et al. 2005). 
The villages should further differ in some key factors such as the distance from the local district capital, available infrastructure, private sector activities (e.g. logging concessions, plantations, mining), village size and the quality of the village forest area. The comparison of the three sites (Box 2) allowed me to gain a deeper insight into the different effects decentralisation had depending on key factors triggering changes at the village and household levels.

\section{Box 1. Kutai Barat at a glance.}

\begin{tabular}{|l|l|}
\hline Official establishment of district & October 1999 \\
\hline Population & 147776 people \\
\hline Area & $31628 \mathrm{~km}^{2}$ \\
\hline Population density & 4.67 people/ $\mathrm{km}^{2}$ \\
\hline Population growth & $2.2 \%$ p.a. (1995-2003) \\
\hline Number of subdistricts & 21 \\
\hline Number of villages & 223 \\
\hline Land status & $70 \%$ of area is state forest land \\
\hline Literacy rate & $93.2 \%$ \\
\hline Life expectancy & 69.1 years \\
\hline Mean years of schooling & 7.3 \\
\hline $\begin{array}{l}\text { Adjusted real per-capita expenditure per } \\
\text { month }\end{array}$ & Rp 583 800 (US\$ 64.22 [2007]) \\
\hline Poverty (BPS) & $12.2 \%$ (2002) \\
\hline Poverty (BKKBN) & $48.6 \%$ (2001) \\
\hline Poverty (BTL) & $39 \%$ (2005) \\
\hline Economy & $\begin{array}{l}\text { Swidden agriculture, forest use; timber, coal mining, } \\
\text { gold mining (closing), rubber, rattan, oil palms, livestock }\end{array}$ \\
\hline GDP & $\begin{array}{l}\text { Rp 2.5 trillion (US\$ 275 million [2007]) p.a. (half comes } \\
\text { from mining industry) }\end{array}$ \\
\hline Annual district budget 2003 & Rp 663.2 billion (US\$ 79 million [2003]) \\
\hline
\end{tabular}

Source: CIFOR-BMZ Poverty and Decentralisation Program 2006 (Gönner et al. 2007b).

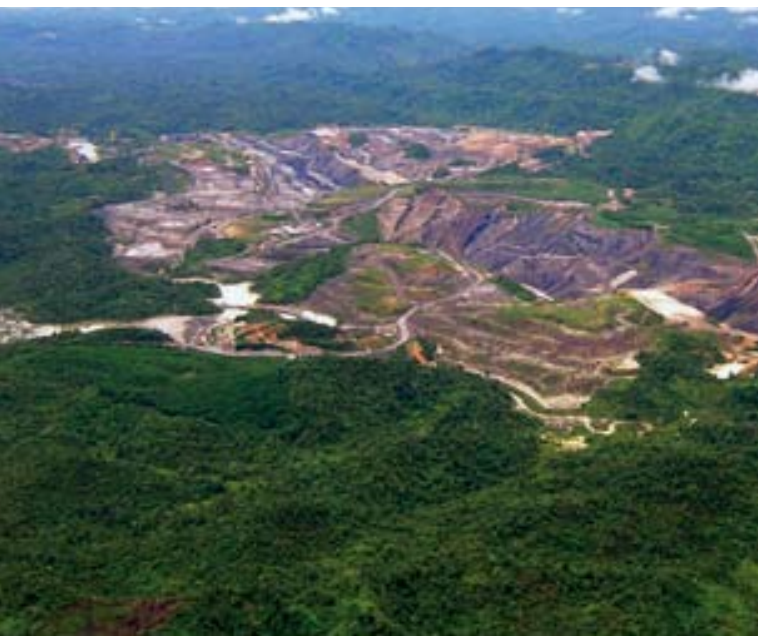

Picture 1: Coal mining in Kutai Barat

Picture 2: Dedication of the new administrative centre of Kutai Barat

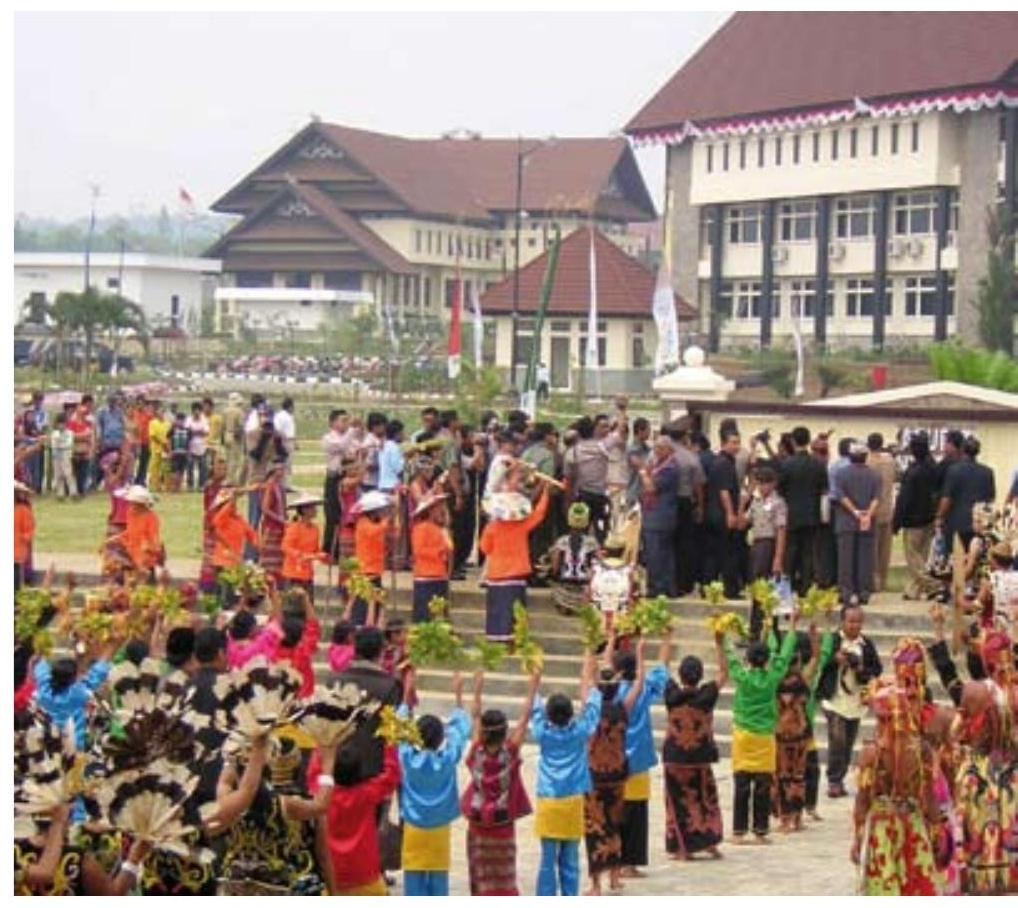




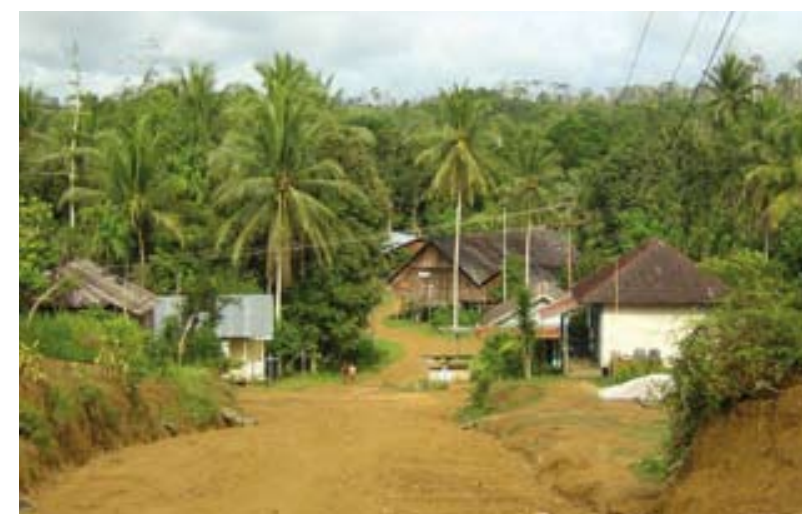

Picture 3: Engkuni Pasek

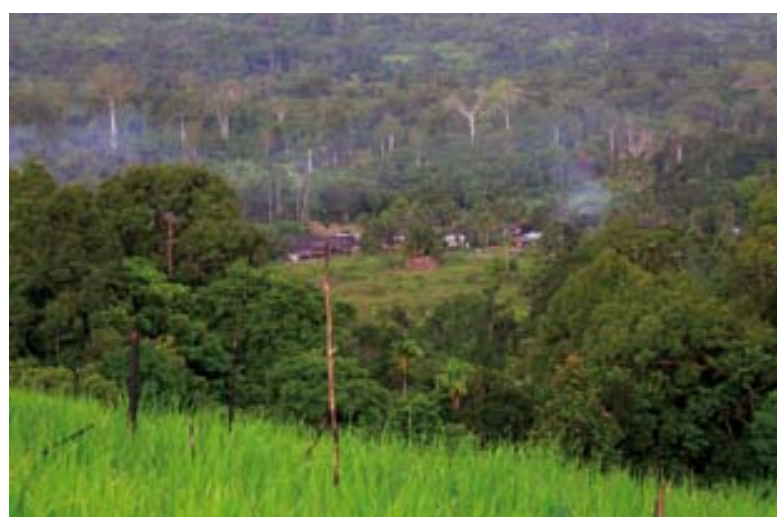

Picture 4: Jontai

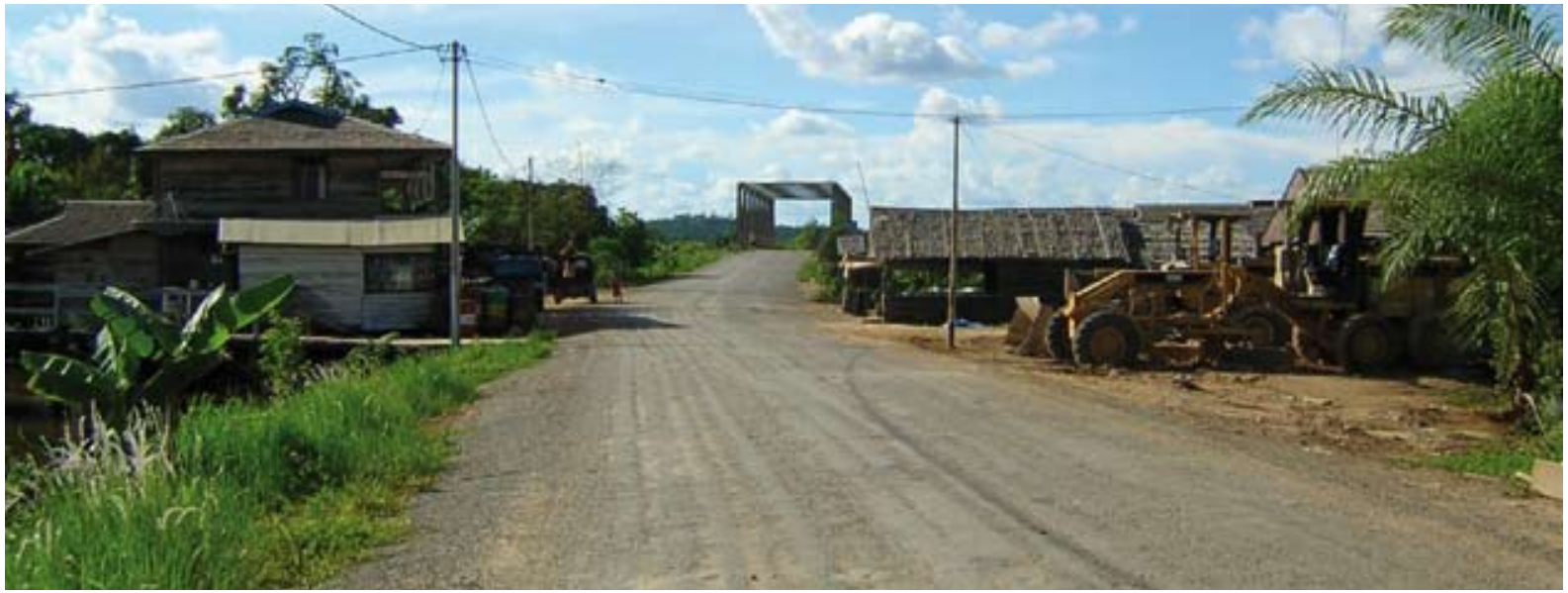

Picture 5: Muara Nayan

Box 2. Overview of the research villages.

\begin{tabular}{|c|c|c|c|}
\hline & Engkuni Pasek & Jontai & Muara Nayan \\
\hline $\begin{array}{l}\text { Distance from } \\
\text { District Capital } \dagger\end{array}$ & $11 \mathrm{~km}$ & $30 \mathrm{~km}$ & $150 \mathrm{~km}$ \\
\hline Population & 362 & 361 & 251 \\
\hline Forest area & Ca. $35 \%$ & Ca. $65 \%$ & Ca. $15 \%$ \\
\hline Forest quality & $\begin{array}{l}\text { Mainly secondary } \\
\text { forest with some small } \\
\text { patches of old forest; } \\
\text { forest partly destroyed } \\
\text { by forest fires in } 1997\end{array}$ & $\begin{array}{l}\text { Mainly old secondary } \\
\text { forest and primary } \\
\text { forest; no destruction } \\
\text { through forest fires }\end{array}$ & $\begin{array}{l}\text { Mainly secondary forest; } \\
\text { large parts destroyed by } \\
\text { forest fires in } 1982 \text { and } \\
1997\end{array}$ \\
\hline $\begin{array}{l}\text { Major income } \\
\text { sources in } 2004\end{array}$ & $\begin{array}{c}\text { Logging, salaries, } \\
\text { rubber }\end{array}$ & Logging, fee payments & $\begin{array}{l}\text { Daily wages, rubber, } \\
\text { logging }\end{array}$ \\
\hline Private sector & None & Logging company & $\begin{array}{l}\text { Palm oil company and } \\
\text { coal mining company } \\
\text { close by }\end{array}$ \\
\hline $\begin{array}{l}\text { Level of formal } \\
\text { education }\end{array}$ & High & Low & Low \\
\hline Poverty (BPS) $\ddagger$ & $19.35 \%$ & $24.75 \%$ & $19.56 \%$ \\
\hline Poverty (BKKBN)§ & $75.19 \%$ & $100 \%$ & $58.93 \%$ \\
\hline SWBף & $31 \%$ feel poor & $48 \%$ feel poor & $72 \%$ feel poor \\
\hline
\end{tabular}

$\dagger$ The distances here are measured as the crow flies; $¥$ SUSEDA Survey 2000; $\$$ BKKBN Survey 2002; 9 own data 2004. 
Figure 2. Map of Kutai Barat with the location of Enkuni Pasek, Jontai and Muara Nayan.

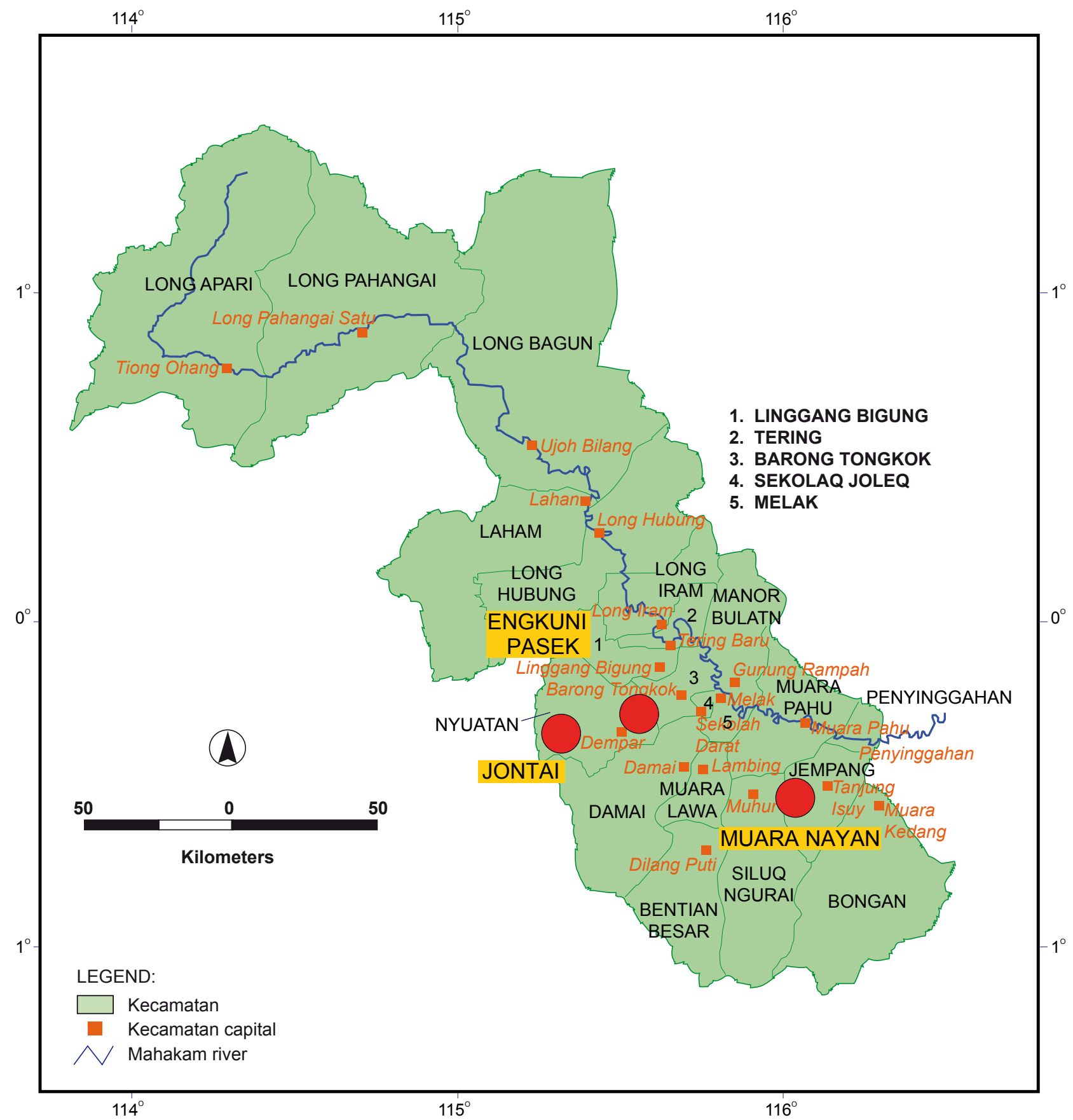

\subsection{The Dayak Benuaq}

The Benuaq are classified as a subgroup of the Luangan Dayak, which together with the Ngaju, Ot Danum and Ma'ayan form the Barito linguistic family of southeast Borneo (Sillander 1995, p. 71). However, as the group identity among the Luangan is particularly low, most Benuaq hardly use the term Luangan and mainly refer to themselves as Dayak, in contrast to the Muslim population of East Kalimantan, or as Benuaq, in contrast to other Dayak groups. When speaking with other Benuaq, they mainly identify themselves with the river they live by, e.g. as Benuaq Idaatn or Benuaq Ohookng. The population of the Benuaq is estimated at between 
20000 and 23400 people (Massing 1981, p. 86; Weinstock 1983, p. 205). Their current settlement area reaches from the Bongan in the east over lake Jempang to the Tunjung Plateau in the north, as well as over the drainage area of the Kedang Pahu to the tributaries of the Teweh in Central Kalimantan (Gönner 2001, p. 36).

The religious practices of the Dayak Benuaq form an integral part of their adat (customs) and today are referred to as Hindu Kaharingan religion. ${ }^{11}$ As an orally transmitted belief system, Kaharingan neither comprises formal written texts nor the worship of deities. Great importance lies instead on various spirits, which can have crucial impact on peoples' lives. The most important rituals are shamanistic curing rituals (belian) and the secondary mortuary ceremonies (kwangkai). Despite Christianisation and modernisation, traditional rituals play a vital role in Benuaq villages throughout Kutai Barat. This is possible because most people perceive adat and Christianity not as contradictory belief systems, but rather connect them in a complementary way.
While previously most settlements consisted of a longhouse (lou), the comprehensive social entity today is the village community, consisting of onefamily houses. Some villages though still have a longhouse, which they often use for meetings, large rituals or as a tourist attraction.

Most Benuaq households (pokatn) comprise three generations and are led by the male head of the household (tuha pokatn). One household mainly consists of several nuclear families, with the head of the family referred to as kepala keluarga. ${ }^{12}$ While all members of a household usually share food and equipment, financial matters are managed individually within each nuclear family. Despite the fact that men are commonly accounted as family or household head, men and women have equal status and rights in the Benuaq society and women take active part in decision making at all levels.

Sincetheestablishmentofthevillageadministration $\mathrm{law}^{13}$ in 1979 , the political organisation of a village has been characterised by a dual leadership system with the mayor (kepala desa or kepala kampung) and

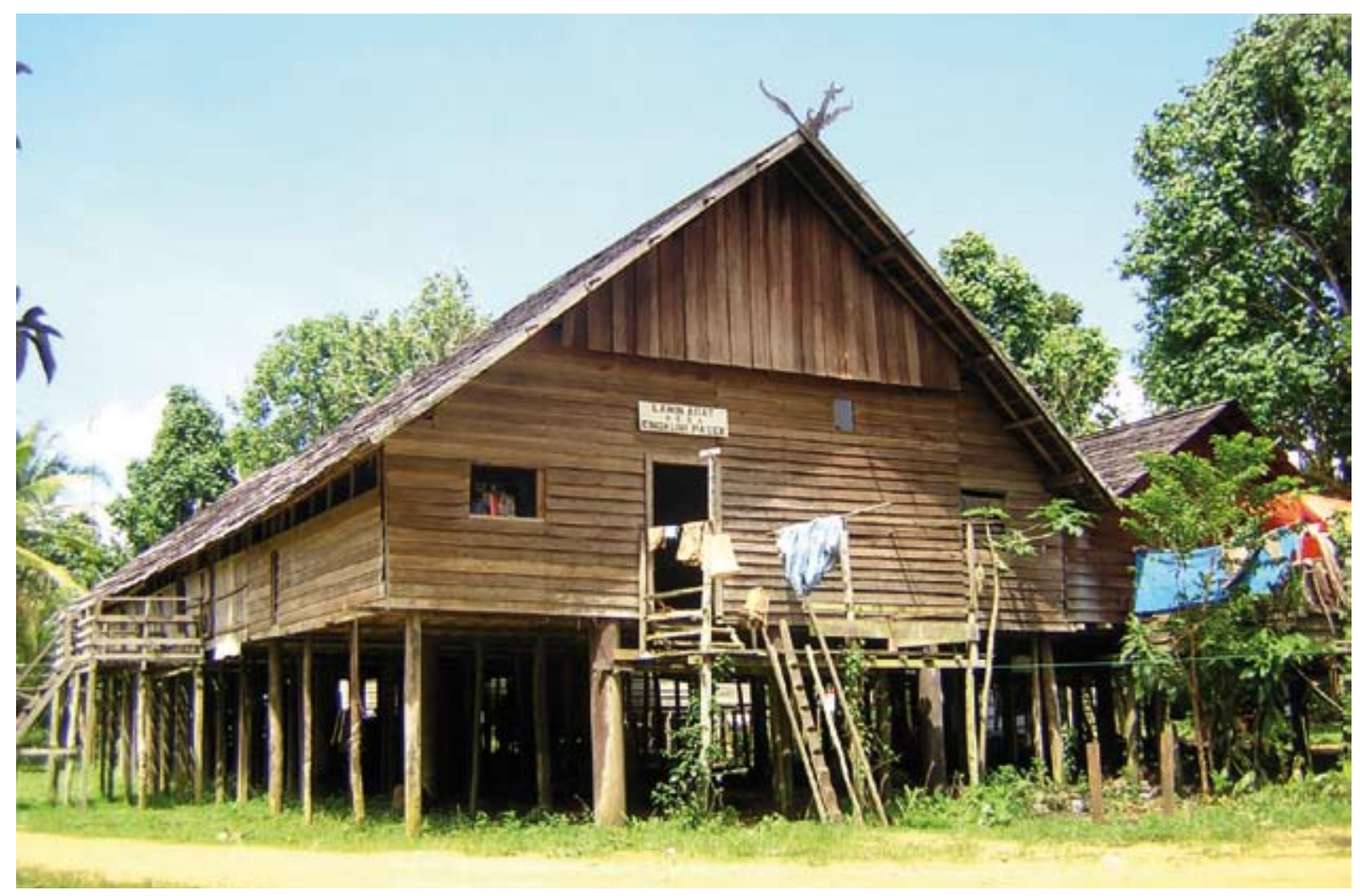

Picture 6: Longhouse of Engkuni Pasek 


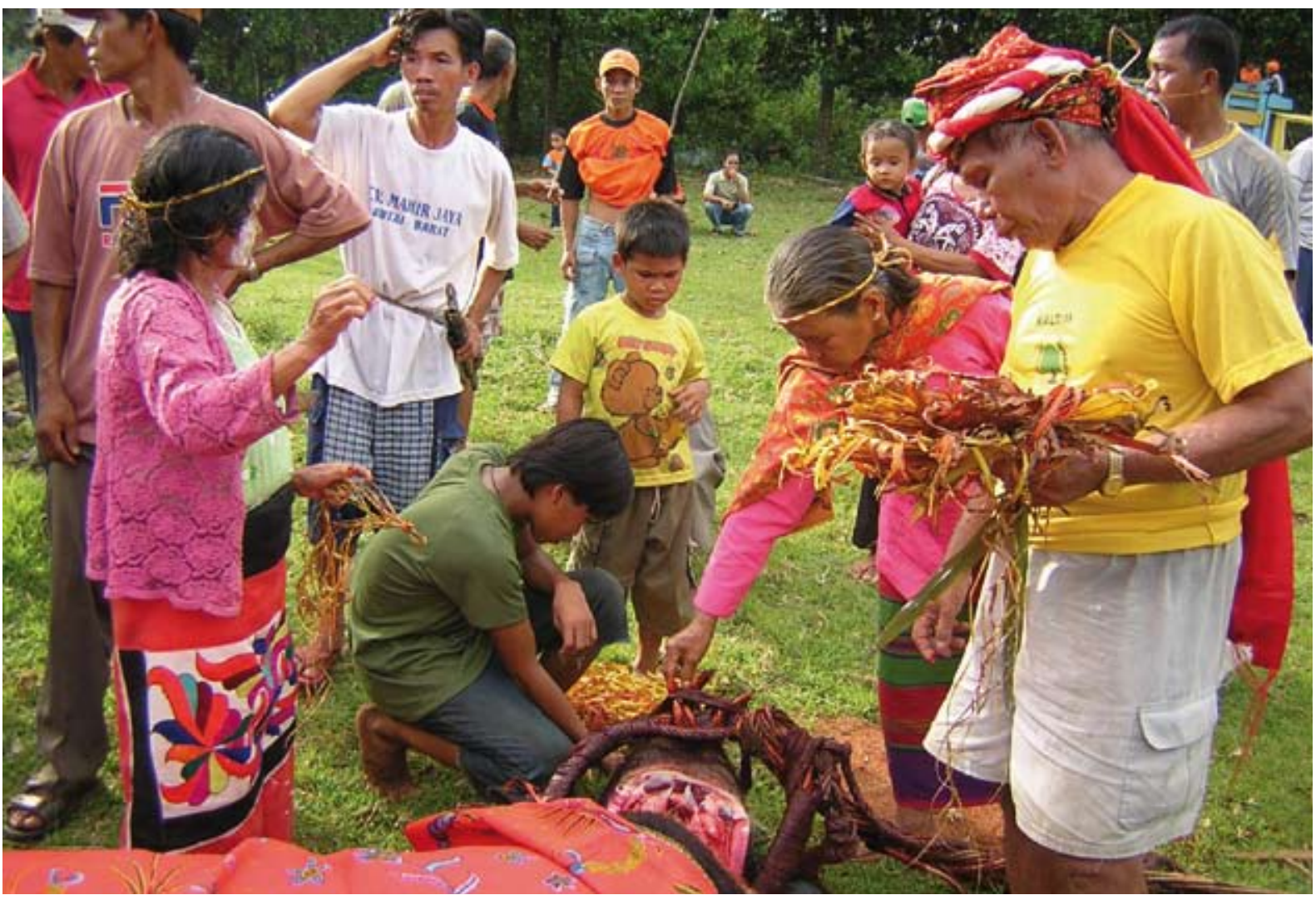

Picture 7: Buffalo sacrifice during a belian ritual

the adat-elder (kepala adat) being joint heads of the community. With the implementation of the new community council (Badan Perwakilan Kampung, $\mathrm{BPK})^{14}$ after decentralisation, the village leadership has now become tripartite. The previously quite farreaching power of the BPK to control the mayor has been reduced with the new decentralisation law. Their main task is now to channel the aspirations of the village community and to issue village regulations.

The Dayak Benuaq practise an extended subsistence economy, which is characterised by a combination of subsistence strategies and a variety of other economic activities which are integrated into the surrounding market economy (Gönner 2001, p.
171). Historically, this combined economic strategy has grown out of the trade in forest products, which linked the Benuaq to international trade for several centuries. The most important market products are rattan and rubber, which are sometimes collected in the forest, but mainly grown in rattan and rubber gardens. Additionally, they produce a variety of other forest products which are grown in forest gardens, called simpukng or lembo. The combination of swidden agriculture for subsistence, extracted and cultivated forest products, and additional wage labour, forms the basis of most livelihoods in Engkuni Pasek, Jontai and Muara Nayan. 


\section{Case Studies}

\subsection{Poverty Perception of the Dayak Benuaq}

\section{Leading a good life}

The Dayak Benuaq share a common understanding of poverty, which is largely based on a household's economic situation. Commonly, people are considered 'poor' if they suffer material deprivation and experience difficulties in fulfilling basic needs such as food, housing and clothing, while people are considered 'rich' on the basis of obvious material wealth. However, in the Dayak Benuaq language no uniform expressions ${ }^{15}$ for 'poor' and 'rich' exist, and people mainly use the Indonesian terms 'miskin' and 'kaya'.

Beyond this rather economic understanding of poverty, the Dayak Benuaq share an emic concept of a good life, which they call bolupm bueq, ${ }^{16}$ and a bad life, which is called bolupm daat. These concepts comprise a broad variety of economic, social, political, physical and emotional aspects. A bad life (bolupm daat) is accordingly characterised by a lack of all means, including not being able to fulfil primary needs, being old and sick, having no income and no job, being socially excluded, having no wife or no husband, and feeling weak and insecure. Conversely, a good life (bolupm bueq) is characterised as a condition where all demands are fulfilled and a person experiences no deprivation of any kind. One of my key informants summarised it in the following way: 'a good life means that all is there, while a bad life is characterised by a lack of everything'.

A good life is something one has to strive for. Many informants told me that a good life can only be reached through strong personal efforts. One man in Jontai explained: 'To reach a good life you have to be young and able to work hard, so you can open a large rice field, plant many gardens and raise animals, then you can sell them and earn money...' Income and work form important requirements to reach a good life, but people stress that this is not all: 'A good life doesn't simply mean to be rich. A good life includes education, being healthy and free of burdening thoughts', one informant told me. It is also of great importance to take care of personal relations, as one woman explained: 'If you want a good life, you should never quarrel. I often quarrel with my husband, but that makes my life difficult—my heart can't be happy'.

A Benuaq proverb illustrates how a bad life feels: Ijei ngetetepaq, lokukng ngerempolatthe caterpillar has become as small as a louse and its movement is already like that of a worm'-implying that those who suffer a bad life are deprived of their ability to act and can hardly move anymore. All in all, this local concept of a good and a bad life is strongly reminiscent of the concepts of wellbeing (as discussed in Gönner et al. 2007a) and illbeing (as used by e.g. Narayan et al. 2000a, b). 


\section{Box 3. Local poverty indicators.}

When asked to distinguish between poor and well-off households in the village, the villagers used the following indicators:

Food: sufficient rice, meat and vegetables, frequency of eating

Housing: ownership, size, building materials of roof, walls and floor, use of paint and glass windows, amount of kitchen equipment and cleanliness of the house in general

Clothing: variety of clothes, quality of clothes, and frequency of clothes shopping

Health: health condition, ability to use medical service

Education: level of education and traditional knowledge

Natural assets: ownership of animals, fields and gardens (especially rubber gardens)

Physical assets: ownership of machines. e.g. chainsaw, sewing machine, rice thresher

Vehicles: ownership of push bike, motor bike, or car

Luxury goods: ownership of gold, TV, VCD player, fridge, etc.

Money: amount of cash income, stability of income source, number of income sources, and existence of savings

Social relations: having good relations within the family, with friends and neighbours

In general, people tend to present themselves as poor in contrast to wealthier families within the village or to people in more developed regions of Indonesia. However, they distinguish their situation from other kinds of poverty: 'we are not as poor as the homeless people in Jakarta which I see on TV. They have absolutely nothing. They have no food and sleep in cardboard box houses along railway tracks, while we have at least our own rice fields, our own land and our own house, as simple as it might be', a villager of Engkuni Pasek told me. People in Engkuni Pasek, Jontai and Muara Nayan see the major obstacles that prevent them from reaching a good life as the lack of opportunities to earn a (stable) income, their low education level, and the unequal distribution of benefits within the district. Facing their daily difficulties while being aware of the rich natural resources around them, several informants stated: 'we are like mice that starve in a rice barn'.

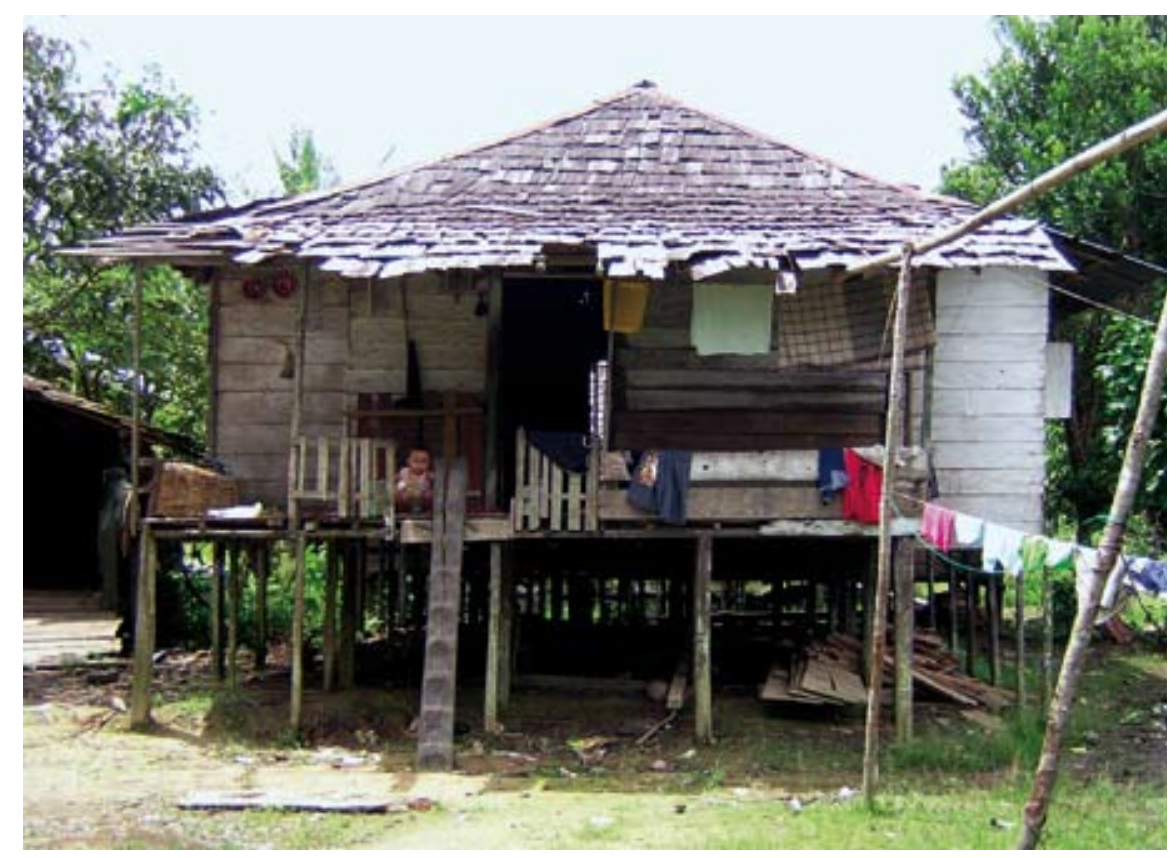




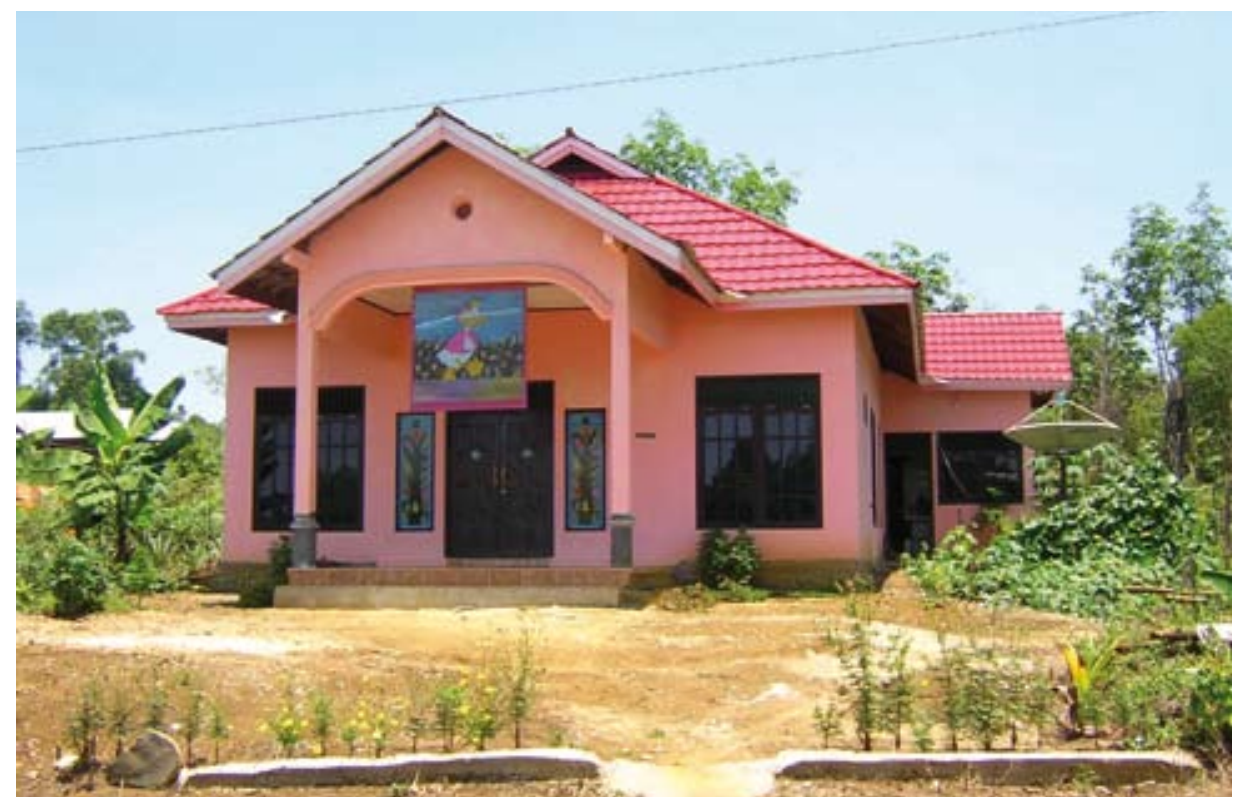

Inequality - old or new phenomenon?

In former times, the wellbeing of a person was strongly influenced by the social position she or he held within the stratified Benuaq society. Nobles (mantiiq) were usually associated with economic wealth. They had slaves at their command assuring their food supply, and additionally could assert their claims to the labour of the common villagers, from whom they further received shares of their rice harvest and kills. The vast majority of the population belonged to the middle stratum of commoners, which was called merentika or angee. The lowest stratum was formed by slaves or bondmen and bondwomen, called ripatn. Through debt, free merentika could (temporarily) decline in rank and become ripatn. However, most slaves were bought or captured during war raids (Massing 1981, p. 89) and could be sacrificed in the context of large rituals.

With the official abolishment of slavery and head hunting after Indonesian independence, the social stratification of Benuaq society was abandoned. The increasing integration into national administration and a monetary market economy led to a new dispersion of power and prestige, with the former stratification being practically invisible (Massing 1981, p. 89; Gönner 2002, p. 51). However, among one another the people of a village still remember their respective social backgrounds, and it does still play a role in some places, especially when it comes to questions of political power. With decentralisation, inequality in the villages increased, as the new economic opportunities were not equally accessible for everyone. New jobs within local government were limited to those with a relatively high level of formal education. The option to get involved in logging activities depended very much on one's personal physical strength, the ownership of a chainsaw and the skills to operate it, while the benefits from compensation and fee payments depended heavily on a person's aptitude to deal with the companies involved, as well as on one's power position within the village (see below).

\section{Most important wellbeing aspects}

In the wellbeing survey, all respondents were asked to name the three aspects which were most important to their wellbeing (Fig. 3). The most often mentioned aspects fall within the aggregated categories of 'work and income' (18\%), 'social relations' (17\%) and 'education' (16\%), followed by 'food' (12\%), 'health' (10\%) and 'housing' (9\%). One can thus conclude that the fulfilment of 'basic 
Figure 3. Importance of wellbeing aspects across the three villages.

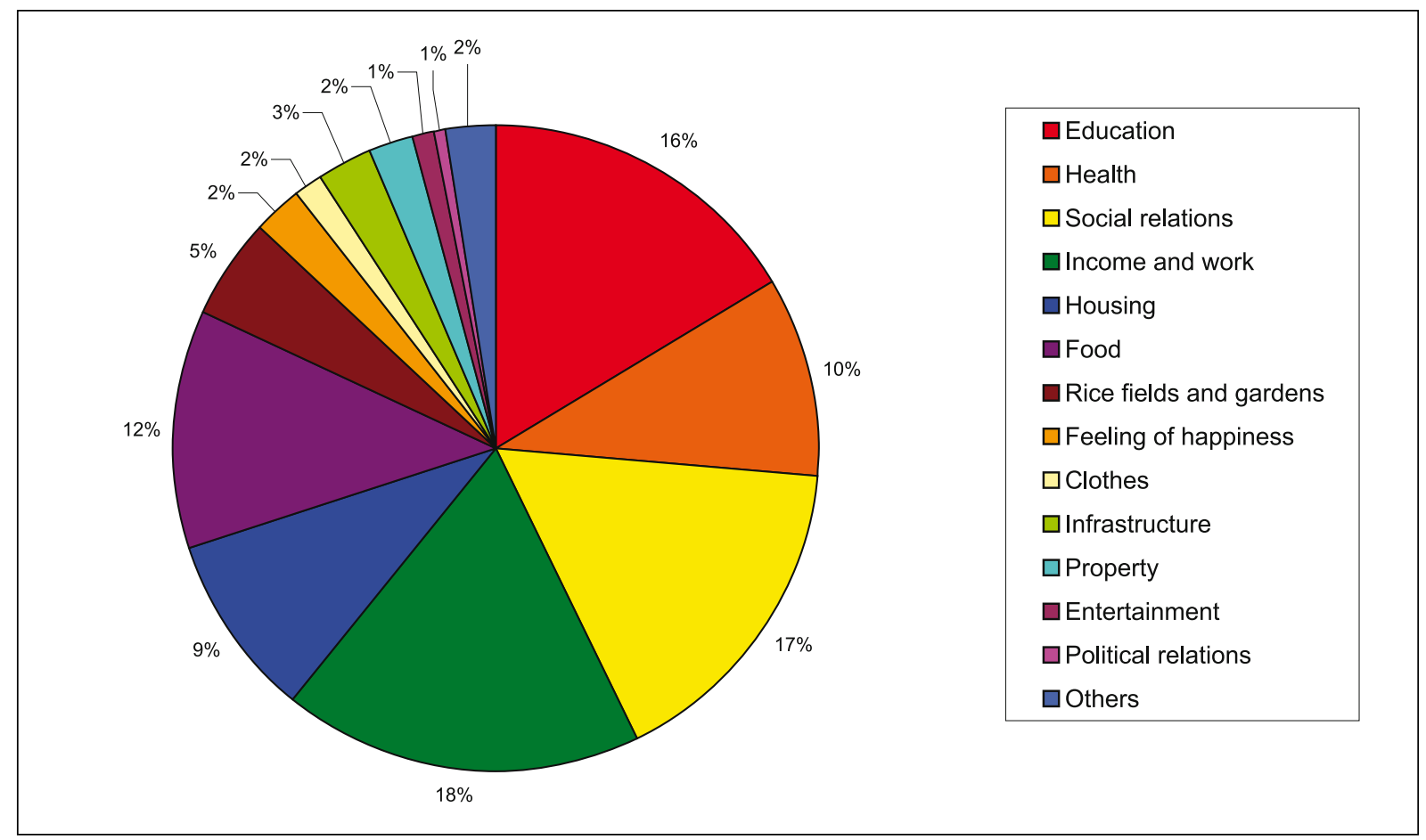

Figure 4. Importance of wellbeing aspects by gender.

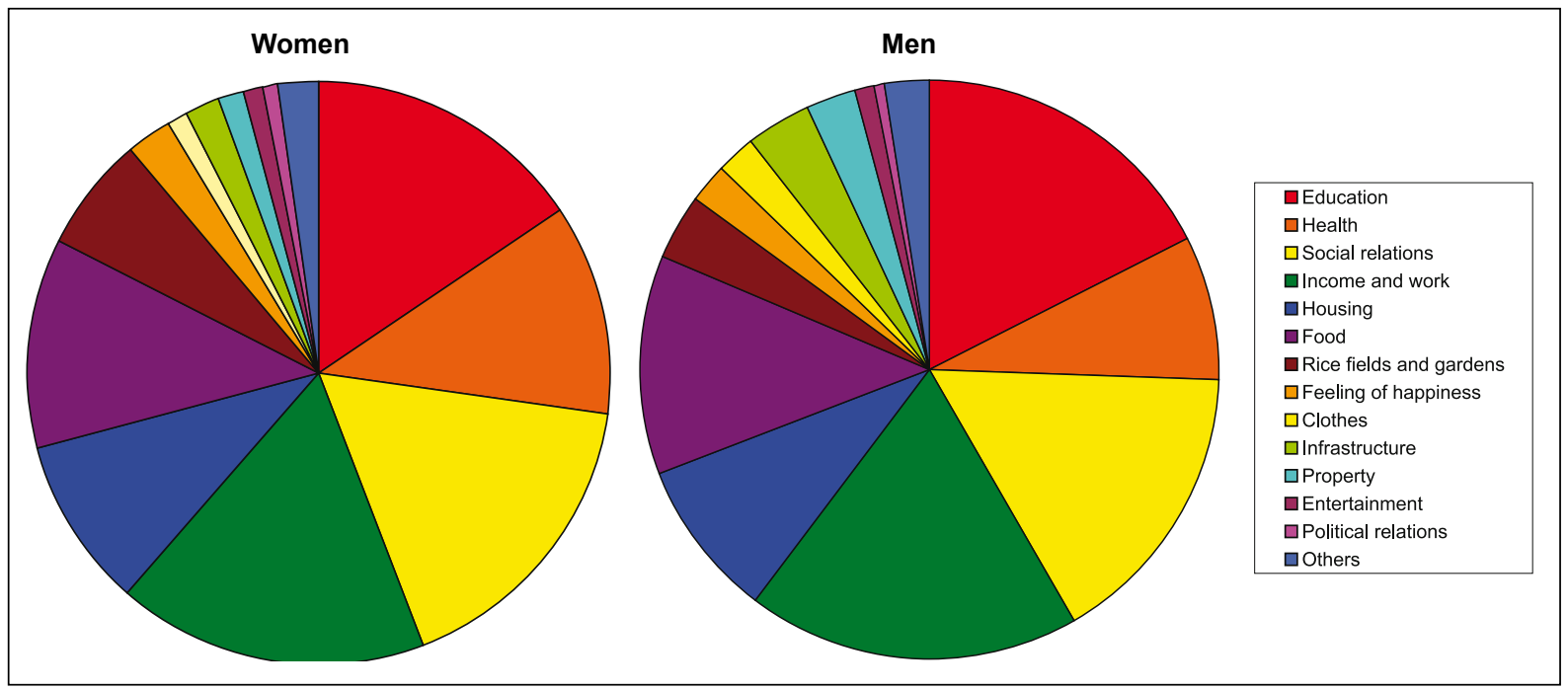

needs', an economically secure livelihood and good social relations form the heart of Benuaq wellbeing.

These results varied only a little among the villages. In Engkuni Pasek, 'social relations' were considered slightly more important than in Jontai and Muara Nayan, where 'income and work' were valued higher - a fact that might be simply explained through the fact that Engkuni is economically the strongest of the three villages. In Jontai, people expressed a stronger wish for assets and luxury items, which is a result of the fact that Jontai has been much more isolated until recently and people do not yet have as many goods as people in Engkuni Pasek or Muara Nayan do.

The most important wellbeing aspects also varied little by gender (Fig. 4). Men and women perceive more or less the same aspects as important to achieve a good life. Slight differences were found concerning 
Figure 5. Importance of wellbeing aspects by age.

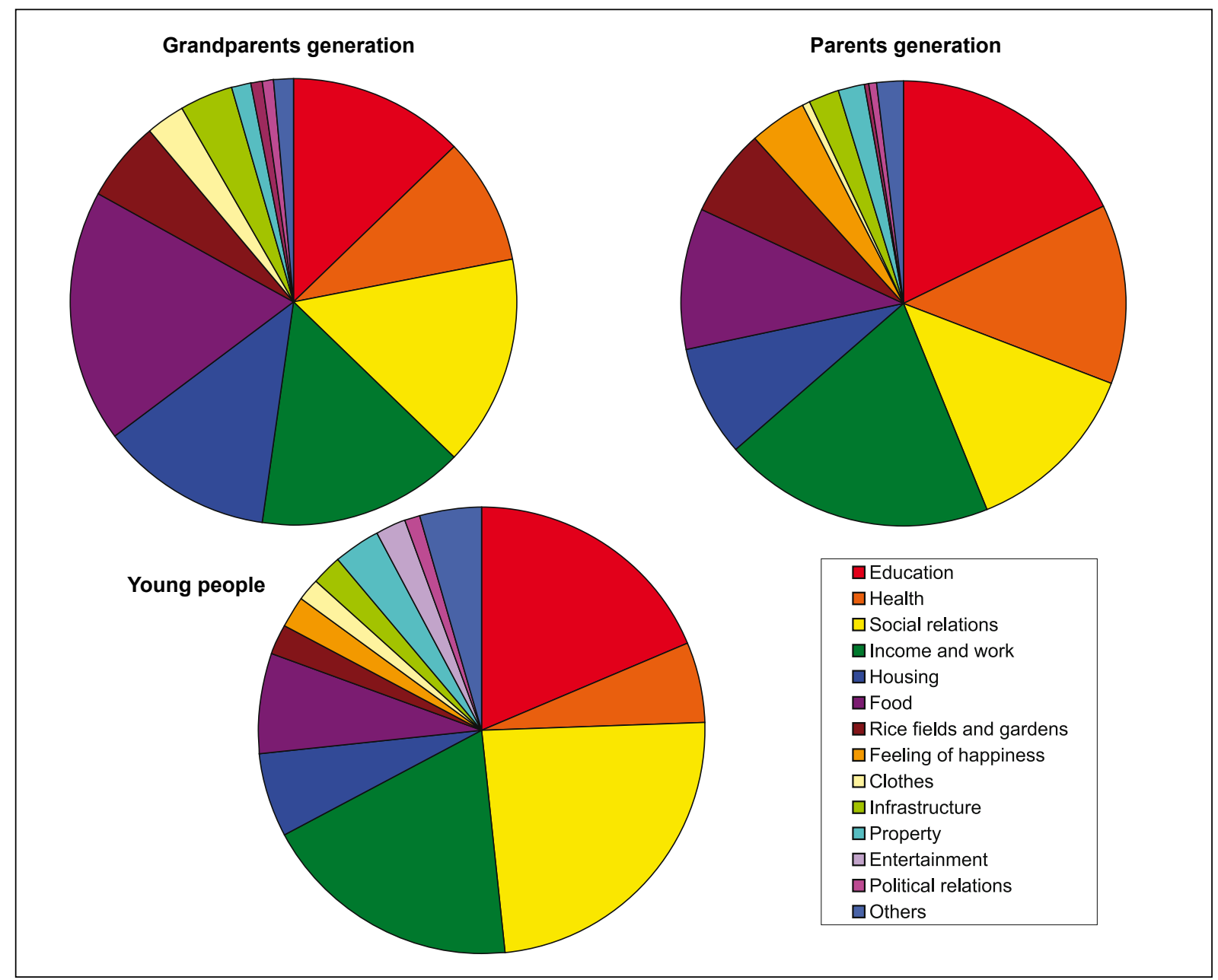

health: women valued health higher, with $12 \%$ of the women and only $8 \%$ of the men mentioning it. I assume that this tendency can be explained by women being more aware of health issues due to giving birth and spending more time in childcare. Furthermore, women more often mentioned the ownership of a field or a garden as important, while men instead valued infrastructure more, especially good quality roads. This might be due to the fact that it is more common for men than for women to gain additional cash income from work outside of the village. Men thus place a slightly higher importance on good transportation facilities.

Much stronger differences were seen between age groups (Fig. 5). Aspects like 'food' and 'housing' were valued high by the grandparent generation, but declined in importance with the parent and even further with the younger generation. The young generation placed a higher importance on social relations, assets and luxury items. The importance of having a 'rice fields and gardens' also declined with decreasing age. However, in comparing this trend between the villages it becomes obvious that the young generation in Engkuni Pasek did not follow this pattern. They still valued rice fields and gardens, which might be explained by the fact that people in Engkuni Pasek derive a relatively good and stable income from their rubber gardens, while people in Muara Nayan and Jontai do not gain much profit from their garden products. ${ }^{17}$

\section{Subjective wellbeing}

Across all respondents, $46 \%$ felt poor, while $26 \%$ judged their wellbeing as in a intermediate condition and $28 \%$ judged theirs as good. ${ }^{18}$ Comparing among the villages (Fig. 6), subjective wellbeing was highest 
Figure 6. Subjective wellbeing in Engkuni Pasek, Jontai and Muara Nayan.

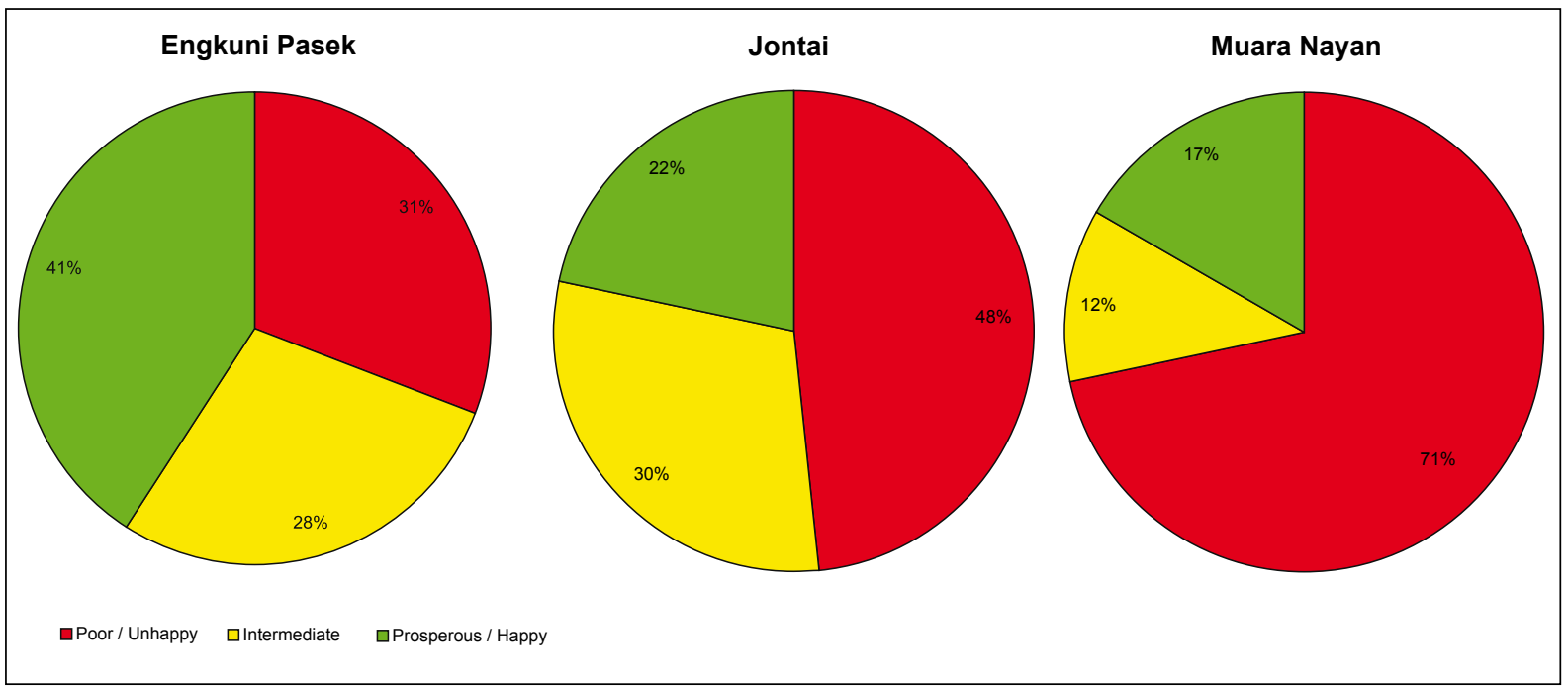

Figure 7. Subjective wellbeing by gender.

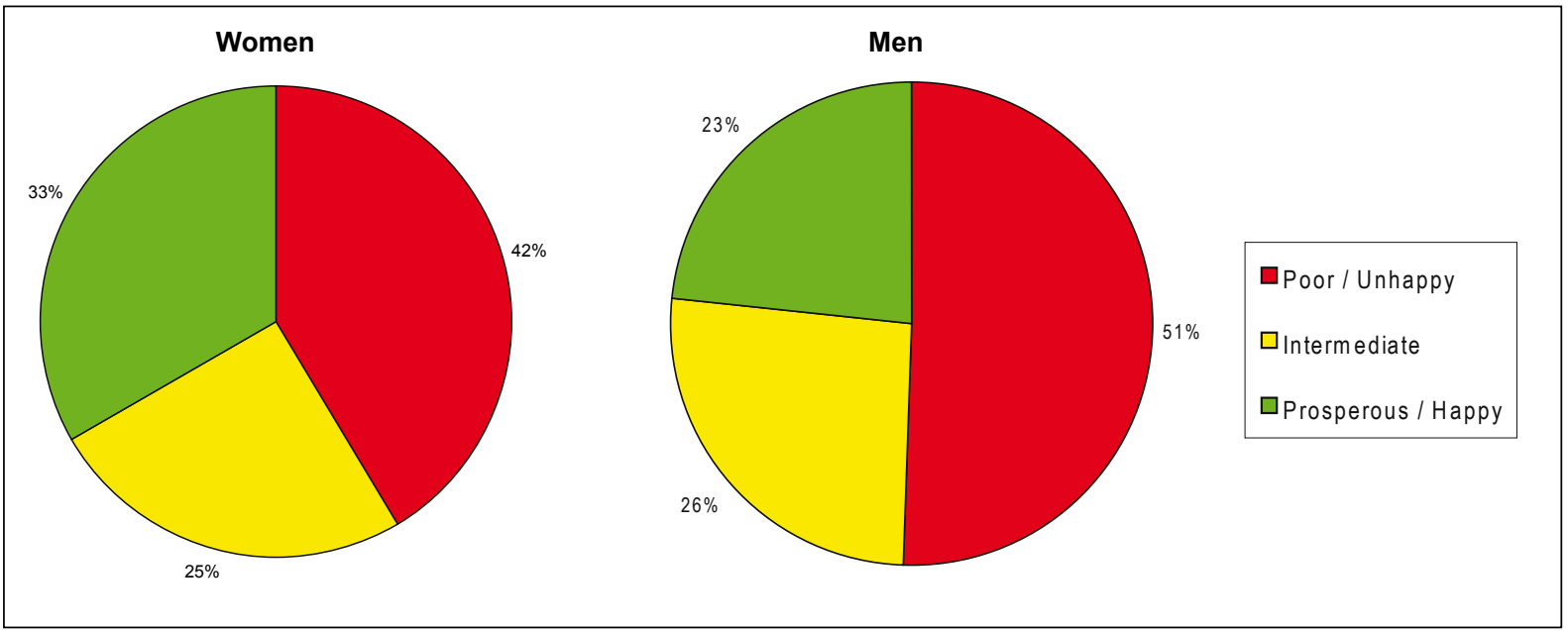

in Engkuni Pasek, where $41 \%$ of the respondents stated that they enjoy a good life, while only $31 \%$ felt poor. In Jontai, $22 \%$ judged their wellbeing positively and $48 \%$ felt poor, while in Muara Nayan a vast majority of $71 \%$ considered themselves as poor and only $17 \%$ stated that they enjoy a good life. The felt poverty in all three villages differs greatly from the survey results of BPS and BKKBN (see Box 2).

Women had a slightly higher wellbeing status than men, with $33 \%$ of the women stating that they enjoy a good life, while only $23 \%$ of the men said so (Fig. 7). This trend is the same in all three villages and in accordance with the findings of Nolen-Hoecksema and Rusting (1999), who evaluated several studies on subjective wellbeing and showed 'that there is a trend toward women reporting greater experience and expression of positive moods than men' ( $\mathrm{p}$. 334). Possible explanations range from biological explanations, over personality explanations to social context explanations, including stereotypes and role models. Which explanation is true for the Benuaq, would be the object of mere speculation.

Subjective wellbeing varied widely with age (Fig. 8). While the percentage of people enjoying a good life remained relative stable in all three generations, the proportion of people who felt poor increased with age from $33 \%$ among the young people to $46 \%$ in the parent generation to $56 \%$ in the grandparent 
Figure 8. Subjective wellbeing by age.

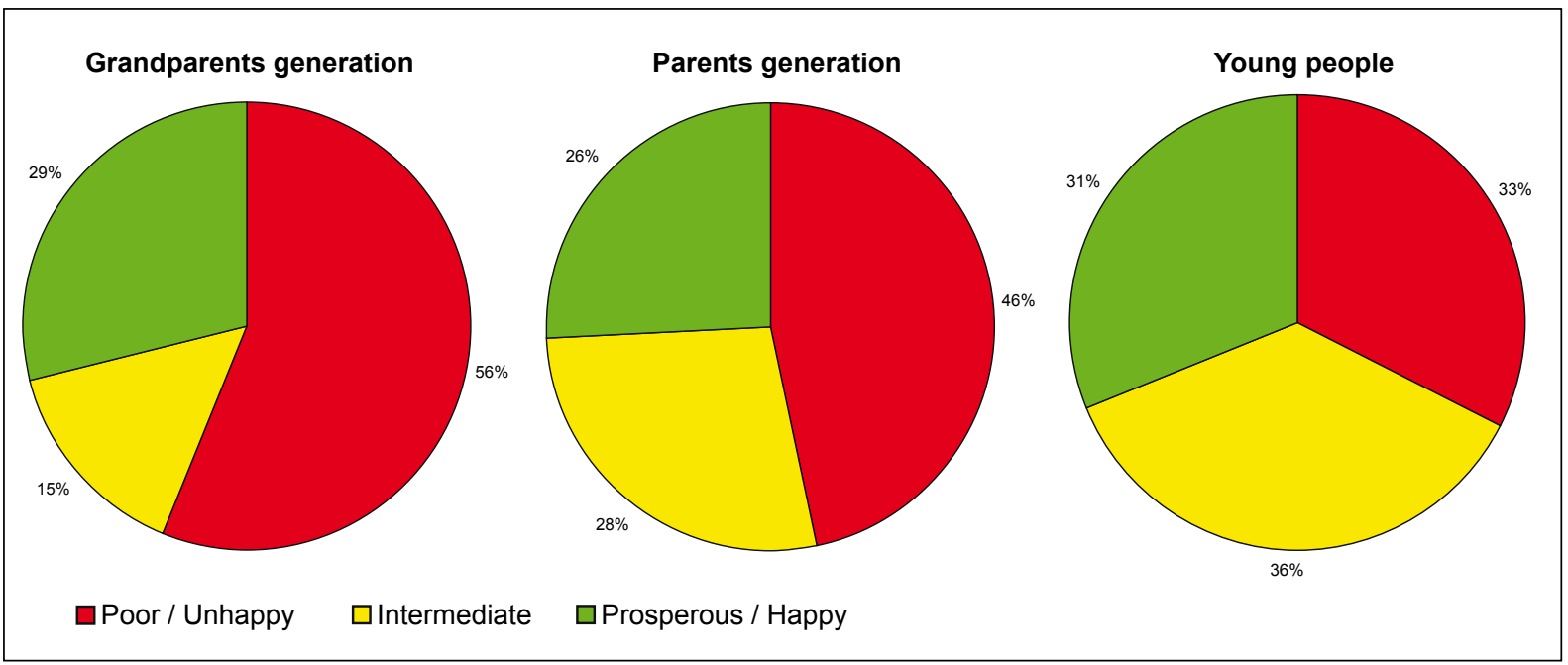

generation. This might be caused by experiences as expressed by two old ladies in Muara Nayan: one said 'my thoughts are still young, but my strength is vanishing...how shall I earn my living?' and the other told me: 'I am old now...in former times I lived upstream with my husband, we had many forest gardens and our children were still complete, then my heart was happy; 10 years ago my husband died and one of our children died as well, our gardens lie abandoned now, our rattan is taken by others and our rubber trees are burnt- the joy of previous times is gone'.

The comparison of subjective wellbeing by age and village (Fig. 9) reveals further interesting insights: the general tendency that old people felt less well than young people held true for Muara Nayan and Jontai. However, a reverse trend was found in Engkuni Pasek, where only 18\% of the grandparent generation viewed themselves as poor, in contrast to $44 \%$ of the parent generation and $27 \%$ of the young people. The grandparents of Engkuni Pasek were also the group with the highest subjective wellbeing, followed by the young generation of Jontai, while the grandparents of Jontai and Muara Nayan were the two groups with the lowest wellbeing. How can the grandparents in the three villages feel so differently?

I suggest that this is mainly, though not exclusively, related to the feeling of life goal achievement. In Engkuni Pasek, most grandparents feel satisfied with their life as their children have reached a relatively high education, offering them better working options. The grandparents thus feel that they have succeeded in life-they achieved a better life for their children and benefit from it as well, through financial support from their children. Grandparents in Jontai and Muara Nayan cannot enjoy this satisfaction yet.

In Muara Nayan, old people expressed the feeling that the overall situation is worsening. Instead of providing a better future for their children, they see them faced with more and more difficulties, e.g. the loss of land to oil palm plantations, the loss of gardens through forest fires, and increasing water pollution caused by near by open-pit coal mining.

The big difference between the old and young people in Jontai might be best explained by the different chances these groups had to take advantage of the new opportunities that opened up since decentralisation. These opportunities were mainly suited to young people, as they are the ones that can operate a chainsaw, profit from new education opportunities and enjoy the new mobility, while many old people feel unsatisfied as they see things moving but cannot take part in them. A man in Jontai expressed this feeling when he told me: 'I have always been poor, my children couldn't succeed but maybe my grandchildren can...' 
Figure 9. Subjective wellbeing by age per village.

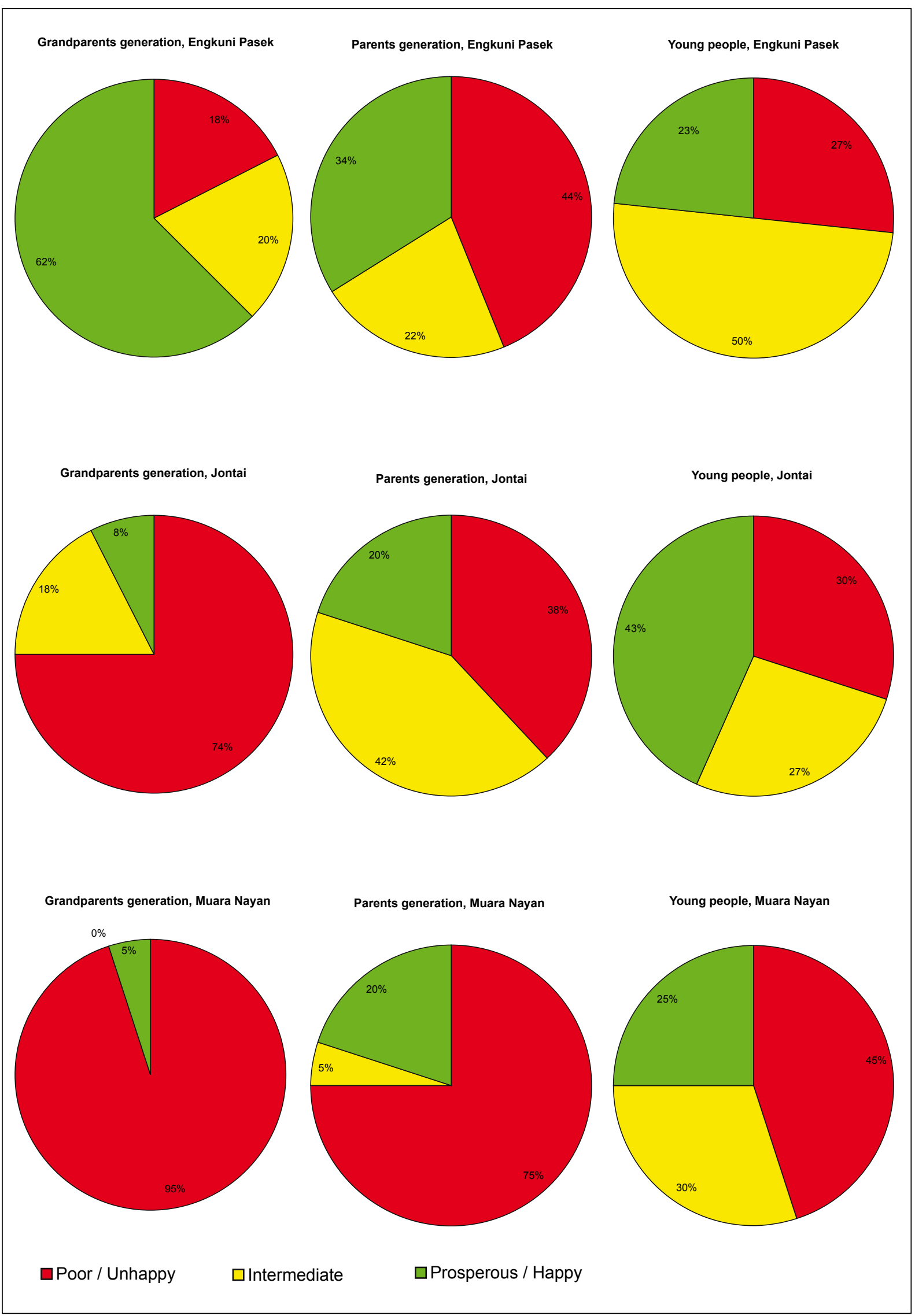




\subsection{Changes and their Causal Relations}

In the following sections, I analyse the changes and their causal relations in each of my three research sites before comparing them to point out common patterns and different trends.

\subsubsection{Engkuni Pasek}

Subjective wellbeing: The villagers of Engkuni Pasek generally felt empowered and happy about decentralisation, because they immediately saw things moving. They live close to the new centre of Kutai Barat and thus developed a feeling of ownership towards the new administrative centre and feel proud of it. Their subjective wellbeing has further been positively influenced by a rising living standard, as $50 \%$ of the households reported that their household economy had improved over the previous 5 years. This was mainly caused by several new income sources, which are explained below.

Health: Nutrition improved after decentralisation, as the variety of food increased with the development of infrastructure. More food vendors started to come to Engkuni Pasek and through the new income sources people also had the necessary cash available to buy more food. However, the construction of a new road from Sendawar to Dempar passing by Engkuni Pasek led to a decline of drinking water quality, especially for the village part of Engkuni. While Pasek derives its drinking water from a nearby well, people in Engkuni use boiled river water. Rains now wash the dirt from the road into the Idaatn river just above the pipeline that channels the village drinking water. Additionally, the new bridge over the Idaatn, which is part of the new road, has become a popular place for people to wash their motorbikes and cars, further polluting the Idaatn river.

Wealth: With increasing income, material wealth rose in the village. Most people invested their increased income into house building activities and the purchase of machines and luxury items, such as motor bikes, TVs, satellite dishes, VCD players, and generators. The relatively high cash income from (illegal) logging was also often spent on gambling, alcohol and prostitution. Because the new income sources were not equally accessible to all villagers, inequality increased within the village.

Knowledge: In general, the education level in Engkuni Pasek is relatively high, due to a Catholic school which was founded in the village in 1950 . Today, $87 \%$ of the households have at least one household member with an education higher than middle school, and $47 \%$ even have a household member with a university or college degree. While formal knowledge is continuously gaining in importance, traditionalknowledgeisdeclining. Young people are hardly interested in studying traditional rituals, mainly because the apprenticeships are very expensive and time consuming. Knowledge about medicinal plants and traditional farming techniques are disappearing, as most children leave the village after primary school to complete their education in Sendawar or Samarinda, the provincial capital. The increasing availability of western biomedicine further diminishes the knowledge about traditional healing methods.

Natural sphere: The quality of the environment in Engkuni Pasek declined over the previous 5 years. People stated that it was much more difficult to find fish in the Idaatn. The quality of the river water, which is the source of drinking water for Engkuni, has declined through increasing pollution. The village forest, which already suffered during the forest fires in 1997/98, further declined in size and quality through (illegal) logging activities.

Economic sphere: With the creation of Kutai Barat, many new positions were staffed at local government. People of Engkuni Pasek profited well from this opportunity as they live close to the new administrative centre and additionally possess the necessary high level of formal education. Another new income source was (illegal) logging, which was made possible by the legal vacuum that arose after decentralisation because of overlapping, and in some parts contradicting, authorities of local 
and central government. Feeling empowered by the spirit of Reformasi and strengthened by the political acceptance of traditional rights, people dared to take the risk. The improved physical access to the forest through road building activities further contributed to the logging activities. Some people got involved in the logging although they fully realised the damage that was being done to the village forest resources. They said that they had to do so because otherwise they could not keep up with their increasing living costs. Although rubber had already been an income source for a long time, its importance grew over the previous 5 years with increasing rubber prices. ${ }^{19}$ Through a previous rubber project in the area of Barong Tongkok during the 1990s (which wasn't too successful at that time in Engkuni Pasek), people at least became motivated to plant more rubber gardens. Thus, most households possessed productive rubber gardens and could immediately profit from the increased rubber prices. A rubber factory being built in a neighbouring village further motivates people to plant rubber. With the improvement of infrastructure, the availability of goods and the chances to sell their own products have increased, but so did market dependency. Only 6.7\% of the households in Engkuni Pasek were self sufficient in rice in 2004. The saving options in Engkuni Pasek improved over the previous 5 years with the founding of the Credit Union Sempekat Ningkah Olo by SHK in cooperation with Puti Jaji, and the formation of a women's savings group with support of Yayasan Anum Lio.

Social sphere: In Engkuni Pasek, solidarity is still strong in emergency cases and for the performance of rituals, while it is declining for economic work and collective community actions (gotong-royong). Solidarity for farm work is mainly decreasing because fewer families grow rice, and if they have a rice field, they usually have a small one, which can be sown and harvested without additional labour. Many people said that they dislike the obligations that arise from the traditional labour exchange groups ( $p l o u$ ), which work in a rotational cycle and sow the field of one member each day. If they are in need of additional labour, they prefer to pay agricultural workers on a daily basis, and thereby free themselves of return obligations. Many people complained about the decreasing collective community actions and said that the mayor should organise such activities more often, while at the same time they stated that they themselves were too busy to take part anyway! All in all, one can observe a strong trend towards individualisation in Engkuni Pasek.

With the unequal distribution of benefits from the new income options, social jealousy increased within the village. Conflicts within the village and with neighbouring villages also increased sharply. Most of them have arisen over boundaries and contradicting ownership claims, as the value of natural resources (land, forest and even sand) increased. There was also tension in the village about (illegal) logging activities in the village forest. While some people benefited greatly, others refused to take part in it as they feared negative long-term effects. This matter was discussed several times within the village, but neither the adat-elder nor the mayor nor the BPK could settle it.

Political sphere: With the founding of the new district, the political participation and selfdetermination of the formerly marginalised Dayak groups improved and, under district leader Rama Asia, the Benuaq formed the majority of the new district's government officials. Villagelevel participation has been strengthened through the founding of the BPK. Although its influence remained limited, it provided room for committed villagers to voice their needs and aspirations. Village institutions and traditional conflict resolution mechanisms have increasingly faced difficulties in trying to solve the manifold conflicts over natural resources. In some cases, this was caused by people that felt so high spirited by Reformasi that they simply did not want to respect any rules, while in other cases it was caused by the increasing 
amalgamation of claims based on traditional adat law with those made based on national law. The tendency towards more individual ownership of land, which was already noted in 2001 (Haug 2002) increased further during 2004 and 2005, due to the increased value of natural resources.
Through overlapping authorities of central and local government, decentralisation created a legal vacuum. The resulting Wild West like atmosphere led to an enormous increase of illegal logging as 'who dared most gained most'.

\section{Box 4. The logging boom.}

After decentralisation provided the local government the authority to issue small-scale forest concessions, 622 of these 100-ha HPHH licences were issued in Kutai Barat (Andrianto 2006, p. 44). They were granted to individuals, groups or cooperatives, who then worked together with contractors to exploit the forest. Negotiations between the logging companies and the villagers determined the fee the contractor would have to pay to the traditional owners of the forest. These fees varied between Rp 50000 (US\$ 5.50 [2004]) and Rp 150000 (US\$16.50 [2004]) per $\mathrm{m}^{3}$ of timber (Andrianto 2006, p. 45).

\section{What did the various actors do in this new setting?}

Logging companies: used the new situation to gain maximum profit. They violated the boundaries of their logging areas, tried to cheat the villagers, underpaid their workers who mainly ended up in a debtrelation with the company and used paramilitary youth gangs to defend their interests.

Local government: closed its eyes to the well known practices of the logging companies as they gained taxes from them, as well as personal additional benefits.

Youth gangs: used their (mainly physical) power to gain profit by becoming the companies' security personnel, but did not hesitate to threaten even the company leaders in cases where they were not paid well or their own families did not receive the proper fee.

Local NGOs: watched things happening as they could not do much.

Villagers: in most villages, the village elite and their direct relatives received the major shares from fee payments. This unequal contribution led to manifold conflicts among and within households. Additionally, many young men took the chance to cut timber on their own and sell it directly in the forest. As the high cash income was mainly received by men, large parts of it were spent on gambling and in the so called 'cafes' which sprung up like mushrooms in Kutai Barat offering karaoke, alcohol and prostitutes. Many people also invested the high cash income in luxury goods and house building activities, while only a few used it for long-term investments or education.

National government: stopped the small-scale concessions, recentralised the forest sector and started strict controls of illegal logging in Kutai Barat.

Picture 10: Piled up logs

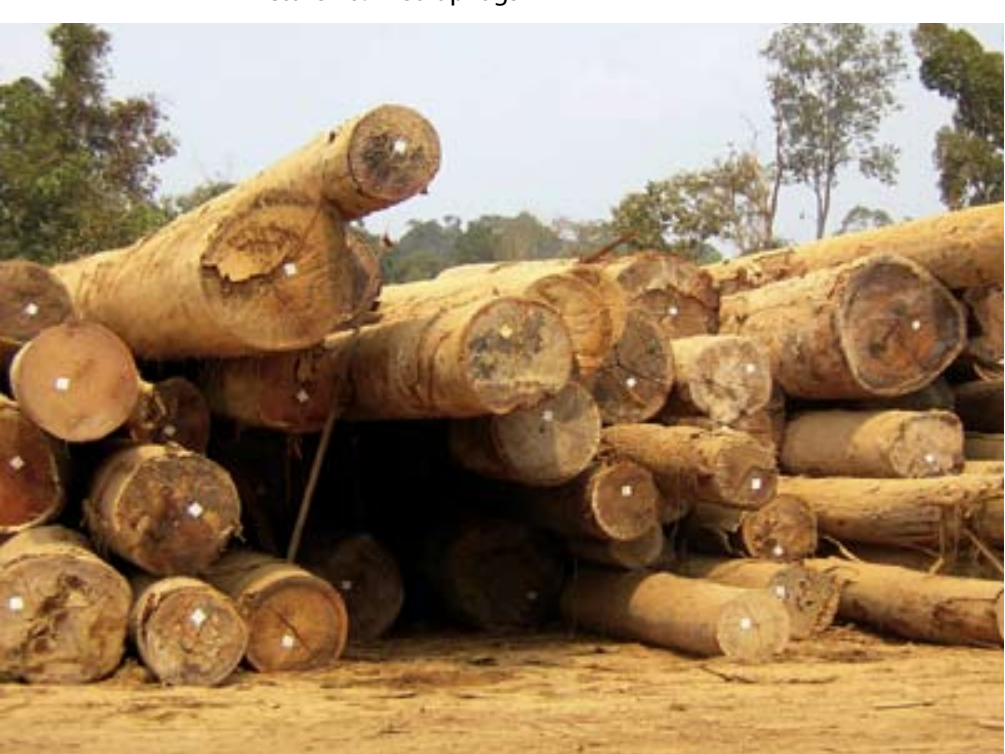

Picture 11: New motor bikes parked in Jontai

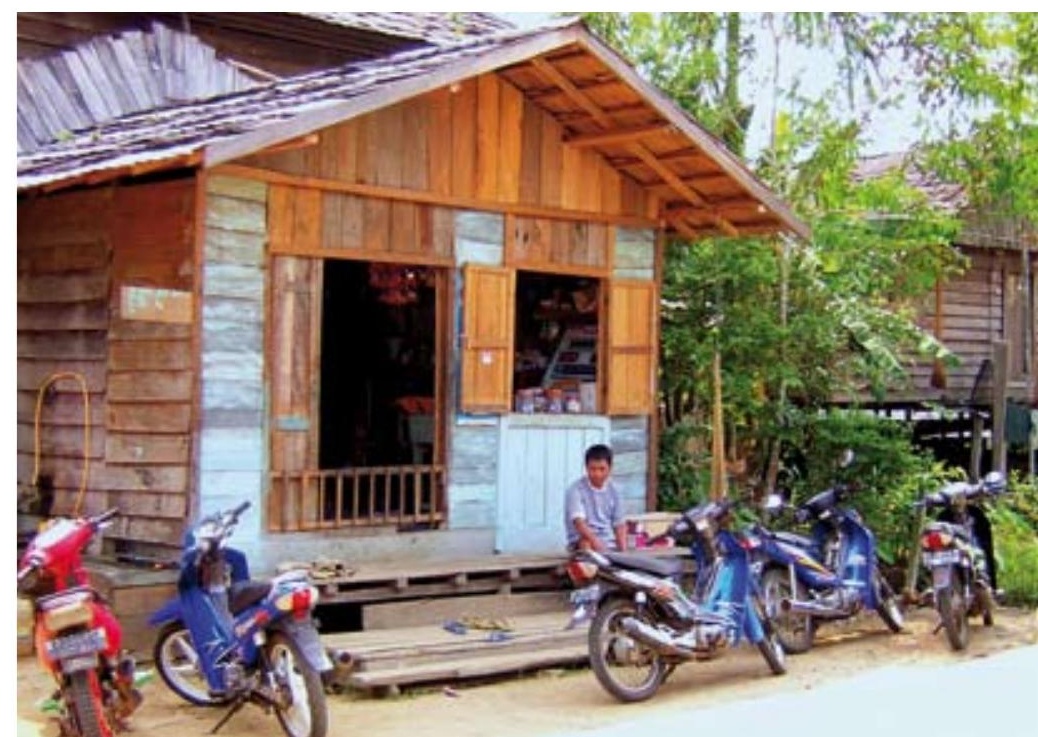


Infrastructure and services: The quality of the infrastructure increased with the construction of two roads and the replacement of two bridges within the village area. Communication also improved as mobile phone signal became available in some parts of Engkuni Pasek. Health services improved as well with the erection of a new hospital in Sendawar and the introduction of the new health insurance system, which includes a subsidised health programme (Askes Gakin) for poor people. The quality of education improved as the number of teachers in the village primary school grew and some teachers received additional training. However, the headmaster complained that support for educational material decreased, as no schoolbook packages are provided anymore. Over the previous 5 years, two new protestant churches started to offer their services in Engkuni Pasek. This is met by reluctant enthusiasm, as the majority of the villagers belong to the more tolerant Catholic church. During my stay in Engkuni Pasek, one of the protestant churches as well as the Catholic church planned new church buildings with financial support from local government. All in all, Engkuni Pasek received more help from local government than before decentralisation (see Table 2) and the overall relationship with local government improved.

Table 2. Development and help programmes in Engkuni between 1999 and 2004.

\begin{tabular}{|c|c|}
\hline Programme & Institution \\
\hline Subsidised rice supply (Beras Miskin) & Local Government (SoSek) \\
\hline Reforstation Programme & $\begin{array}{l}\text { Local Government } \\
\text { (DINAS Kehutanan) }\end{array}$ \\
\hline Health Program JPS & $\begin{array}{l}\text { Local Government } \\
\text { (DINAS Kesehatan) }\end{array}$ \\
\hline Subsidised health insurance for poor people & $\begin{array}{l}\text { PT ASKES and } \\
\text { Local Government (SoSek) }\end{array}$ \\
\hline Bridge over the Idaatn river & Local Government \\
\hline Bridge over the Ncui river & Local Government \\
\hline Improvement of the road to Benung & Local Government \\
\hline $\begin{array}{l}\text { Village support programme in the form of } \\
\text { Rp } 10 \text { million (US\$1100 [2004]) }{ }^{20} \text { per year }\end{array}$ & $\begin{array}{l}\text { Local Government } \\
\text { (DPM) }\end{array}$ \\
\hline Free medical treatment & $\begin{array}{l}\text { Local Government } \\
\text { (DINAS Kesehatan) }\end{array}$ \\
\hline Free health examination at the primary school & $\begin{array}{l}\text { Local Government } \\
\text { (DINAS Kesehatan) }\end{array}$ \\
\hline $\begin{array}{l}\text { Help to renovate the longhouse } \\
\text { in the form of Rp } 10 \text { million (US\$ } 1100 \text { [2004]) }\end{array}$ & $\begin{array}{l}\text { Local Government } \\
\text { (SoSek) }\end{array}$ \\
\hline $\begin{array}{l}\text { Help for the construction of the roof of the Catholic church in the } \\
\text { form of Rp } 2 \text { million (US\$2200 [2004]) }\end{array}$ & $\begin{array}{l}\text { Local Government } \\
\text { (SoSek) }\end{array}$ \\
\hline $\begin{array}{l}\text { Help for the construction of a new Catholic church, with a total value } \\
\text { of Rp } 25 \text { million (US\$2750 [2004]) }\end{array}$ & $\begin{array}{l}\text { Pemda Kutai Barat } \\
\text { (SoSek) }\end{array}$ \\
\hline $\begin{array}{l}\text { Help for the construction of a protestant church, with a total value of } \\
\text { Rp } 25 \text { million (US\$2750 [2004]) }\end{array}$ & $\begin{array}{l}\text { Pemda Kutai Barat } \\
\text { (SoSek) }\end{array}$ \\
\hline Scholarship programme G Nota & Gerakan National Orang Tua Asuh \\
\hline Scholarship programme BKM & $\begin{array}{l}\text { Local Government } \\
\text { (DINAS Pendidikan) }\end{array}$ \\
\hline Scholarship Programme Prestasi & $\begin{array}{l}\text { Local Government } \\
\text { (DINAS Pendidikan) }\end{array}$ \\
\hline Scholarship from PT KEM & PT KEM \\
\hline Vegetable garden project & Yayasan Anum Lio \\
\hline Clean water programme in Pasek & PT KEM \\
\hline Village Development Workshop & Center for Social Forestry (CSF) \\
\hline
\end{tabular}


Figure 10. Summarised wellbeing trends of Engkuni Pasek.

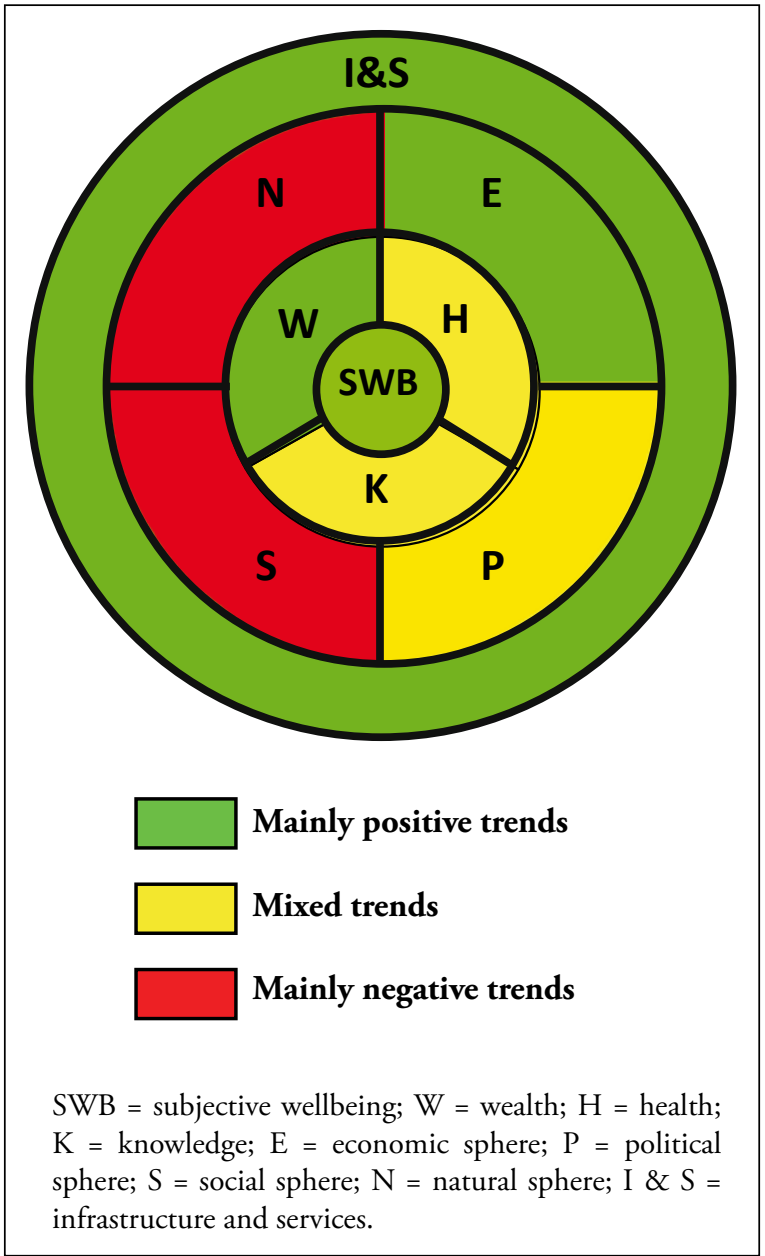

The coloured NESP model (Fig. 10) summarises the wellbeing trends in Engkuni Pasek based on the changes that I observed in the village. Red indicates mainly negative trends, yellow is a sign of mixed trends and green indicates mainly positive trends within the respective sphere.

\subsubsection{Jontai}

Subjective wellbeing: The people of Jontai generally expressed the feeling of being cut off, as their village is not connected to any (asphalted) road yet and there is no bridge over the Nyuatatn river. They also expressed the feeling of lagging behind in comparison to other villages, and commonly stated that they were all poor as they knew about the BKKBN survey which designated their village as being $100 \%$ poor. However, people felt empowered and happy about decentralisation because they felt like their situation was starting to change. Similar to the people in Engkuni Pasek, they developed a feeling of ownership towards the new administrative centre and felt proud about the development of Kutai Barat. Their subjective wellbeing has further been positively influenced by a rising living standard, as $40 \%$ of the households reported that their economic situation had improved over the previous 5 years. This was mainly caused by new income sources from fee payments and (illegal) logging.

Health: The variety of food increased after decentralisation with the development of infrastructure. More food vendors started to come frequently to the neighbouring villages of Sembuan and Dempar, as well as directly to Jontai. Through the new income sources, people also had the necessary cash available to buy more food. The good quality of drinking water in Jontai remained stable as people use spring water, which is channelled from several wells to the village.

Wealth: The increasing income led to a rise of material wealth in the village. Similar to Engkuni Pasek, most people invested their increased income into house building activities and the purchase of machines and luxury items, such as motor bikes, chainsaws, generators, TVs, satellite dishes, and VCD players. However, large parts of the high cash income were also spent on alcohol, gambling and prostitution. Several women complained about their husbands, who squandered their money in 'cafes' instead of taking it home to their families. As people benefited very differently from fee payment and (illegal) logging, the inequality within the village increased sharply.

Knowledge: The education level in Jontai was generally very low, as only $27 \%$ of the households had a member with an education higher than high school. This is mainly due to the (until recently) limited availability and accessibility of education services. With the improved road connection to Sendawar and the construction of a new middle 
school in neighbouring Dempar, junior and senior school attendance increased immediately, as did the perceived importance of formal education. During my stay in the village, the first adolescent of Jontai went to university in Samarinda. However, without the increased income from timber her parents could not have afforded the expensive studies. Traditional knowledge about rituals, medicinal plants and farming techniques was still widespread among the population of Jontai. The increasing wish of young people to continue education after high school in Sendawar or Samarinda might lead to a decrease of traditional knowledge in the future.

Natural sphere: The size and quality of the forest in Jontai declined through both the activities of the logging company and the (illegal) logging of the villagers themselves. Two reforestations programmes that were carried out in Jontai (one focusing on rubber, the other on gaharu) showed only limited success and could not compensate for the large forest loss. People reported that it was increasingly difficult to catch fish in the Nyuatatn river, caused by the unsustainable use of electric fishing methods by some villagers.

Economic sphere: After decentralisation, fee payments and (illegal) logging became the most important income sources in Jontai. Fee payments resulted from an $\mathrm{HPHH}$ concession that was exploited by the villagers in cooperation with a local logging company. Logging (illegal) within the village area was made possible by the legal vacuum that arose after decentralisation (see Box 4). People felt empowered by the spirit of Reformasi and strengthened by the political acceptance of their traditional rights in Kutai Barat. Although their traditionally owned forest officially remained state forest, they could finally freely benefit from it. In one week, an experienced chainsaw operator working on his own location could make a profit of Rp 3 million (US\$ 330 [2004]). In comparison, an average teacher's salary is about Rp 900000 (US\$ 99 [2004]) per month. These high profits, the increasing need for cash due to increasing living costs, an increasing desire for a modern lifestyle, as well as the improved physical access to the forest, further contributed to the high involvement in (illegal) logging activities. The improved road connections and the high cash flow in the village attracted more traders to Jontai, offering all kinds of goods from food, clothes, kitchen utensils, furniture and electrical equipment to false teeth. Despite the increased availability of goods, $30 \%$ of the households in Jontai remained self sufficient in rice in 2004. During my stay in the village, people in Jontai started to plant more plants for commercial use, especially rubber, motivated by the continually increasing rubber prices.

Social sphere: Solidarity for collective community actions (gotong-royong) declined in recent years, while solidarity remained strong in emergency cases, for the performance of rituals and for agricultural work. Although some people started to pay for agricultural work on a daily basis, the traditional labour exchange groups ( $p l o u$ ) were still frequently practised in Jontai. A general trend towards individualisation could be observed in Jontai, although not as strongly as in Engkuni Pasek. The number of conflicts in Jontai increased enormously after decentralisation. While most conflicts with neighbouring villages concerned the respective village boundaries, conflicts between households and among family members mainly arose from unequal distribution of fee payments and different opinions about the proper use of the received payments. Through the unequal distribution of benefits from the new income options, social jealousy increased within the village.

Political sphere: The people in Jontai profited from the generally increasing self-determination of Dayak groups in Kutai Barat. They said that they now enjoyed much better relations with local government than before decentralisation. At the village level, participation had been strengthened through the founding of the BPK. Although its influence remained limited in Jontai, it was used by 


\section{Box 5. Dividing up the forest and the fee.}

The people in Jontai initially decided to share the fee payments equally among all families within the village. However, when the first payment turned out to be only Rp 48000 (US\$ 5.28 [2004]) per family head (kk), they felt disappointed and abandoned this method.

Instead they split into groups based on common ownership claims to certain forest areas and divided up the village forest according to their different 'locations'. Each inheritance group was represented by a (partly self-appointed) leader who was responsible for the arrangements with the logging company, controlled the actual amount logged in the groups' area and made sure that the company would pay the correct amount. These leaders then had to share the fee payments among all members of the inheritance group, whereby the leaders got a larger share as they had the trouble of dealing with the company.

The fee payment a person received could vary-according to the honesty of the group leader, the size of the respective location, as well as the number of people belonging to his or her inheritance groupbetween Rp 200000 (US\$22 [2004]) and Rp 15 million (US\$ 1650 [2004]). Single children had a definite advantage, as did people in powerful positions, as it was the village elite with noble origin that received the highest profits.

committed villagers to form village regulations and become engaged in village politics. The traditional land rights system of the Benuaq commonly distinguishes between individual ownership, descent group ownership (rempuuq) and communal ownership. Fields, gardens and areas of secondary growth are mainly owned individually or in the form of rempuuq. The unopened primary forest belongs to the village community as a whole, although families claim use rights to certain parts of the forest, which have been already used by their parents or grandparents to hunt and gather forest products. With the introduction of the $\mathrm{HPHH}$ regulation, these regularly used areas have now been claimed as owned by the respective families in order to receive the fee payments from these areas. The increasing value of natural resources thus led to a stricter perception of rights and an increasing importance of (individual) ownership. Traditional conflict resolution mechanisms in Jontai were effectively solving conflicts over forest tenure at village level, but increasingly faced difficulties in solving conflicts that involved outsiders.

Infrastructure and services: The infrastructure improved with the construction of a new asphalted road from Sendawar to Dempar and Sembuan. The new road immediately diminished not only the real but also the felt distance from Jontai to Sendawar. However, Jontai is still cut off as one has to cross the Nyuatatn river by ferry in Sembuan and then continue on a $1 \mathrm{~km}$ dirt track in order to reach the village. Although people occasionally still use longboats, transportation has mainly shifted from river to road. Electricity and mobile phone signal became available during my stay in the village. Health services improved through the construction of a new hospital in Sendawar, a new clinic (Puskesmas) in Dempar and the introduction of Askes Gakin. Education services improved as well, with the construction of a new junior high school in Dempar, which is planned to be enlarged to comprise a senior high school as well. All in all, Jontai has received more help from local government since decentralisation (see Table 3). During my stay in Jontai, a new Pentecostal church started to offer its services in addition to the two existing protestant churches.

The coloured NESP model (Fig. 11) summarises the wellbeing trends in Jontai based on the changes that I observed in the village. 
Table 3. Help programmes in Jontai between 1999 and 2004.

\begin{tabular}{ll}
\hline Programme & Institution \\
\hline $\begin{array}{l}\text { Opening of a track from Dempar to Jontai } \\
\text { Cementing of the village lane }\end{array}$ & Programme P2D \\
Help for the construction of an adat assembly hall & Programme P2D \\
Health Programme JPS & Local Government \\
Subsidised Health Insurance (Askes Gakin) & Local Government \\
& PT ASKES and \\
Programme to improve unreasonable housing conditions & Local Government (SoSek) \\
& Local Government \\
Support for the construction of a protestant church, to the value of Rp 15 million & (DPM) \\
(US\$ 1650 [2004]) & Local Government \\
Two reforestation projects & (SoSek) \\
Health Programme to fight tuberculosis & Local Government \\
Agricultural Training & (Dinas Kehutanan) \\
Agricultural Programme (provision of seeds) & Yayasan Anum Lio \\
Garden Programme (training and vegetable seeds) & Yayasan Anum Lio \\
Fish Pond Programme & BIOMA and Kehati \\
Chicken Breeding Programme & BIOMA \\
Sports equipment & BIOMA \\
\hline
\end{tabular}

Figure 11. Summarised wellbeing trends of Jontai.

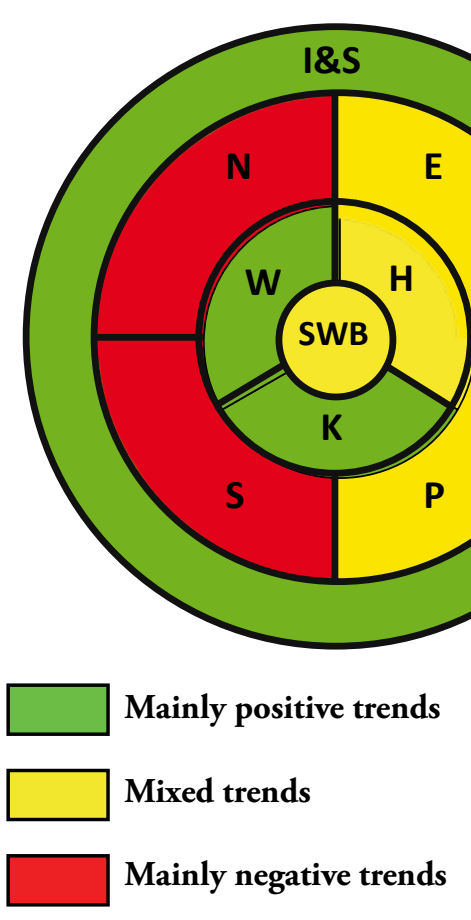

\subsubsection{Muara Nayan}

Subjective wellbeing: In Muara Nayan, nobody felt enthusiastic about decentralisation. While the village had been close to the heart of the old district of Kutai, they found themselves now placed at the periphery of the new district of Kutai Barat. The people in Muara Nayan and the surrounding villages thus developed no feeling of ownership towards the new administrative centre in Sendawar and perceived the glamorous new office buildings simply as a waste of money. They felt that changes were going on in Kutai Barat, but stated that they were not taking place for them. People in Muara Nayan also did not experience a significant improvement of their living standard, as $75 \%$ of the household reported that their situation had remained stable or fluctuated over the previous 5 years. Their subjective wellbeing had further been negatively influenced by the overall increasingly difficult situation in the village and the conflicts that arouse with the opening of an oil palm plantation in 1996/97 and continue in part until today (see below).

Health: Water quality of the local rivers Ohookng and Nayan declined due to increasing pollution from pesticides and fertilisers used in the oil palm plantation, as well as from acidic rock drainage from an open-pit coal mine located upstream from Muara Nayan. While most people 
previously used boiled river water to drink, they now fetch drinking water and water for infant care from wells around the village. Some of these wells are several kilometres away from the settlement and therefore difficult to reach for people who do not have a motorbike. During my stay in the village, many people complained about skin problems after bathing in the Ohookng river and the women who were spraying pesticides as daily wage labourers at the oil palm company regularly complained about headaches.

Wealth: Over the previous 5 years, material wealth had increased within the village, as did inequality. Items most frequently bought included TVs, motorbikes, VCD players and generators. Although several 'cafes' sprung up in the vicinity of the coal mining company, this seemed to have been of minor importance for people in Muara Nayan, maybe because their income from (illegal) logging was not as high as (e.g.) the fee payments in Jontai, and people therefore felt less tempted to spend it on amusement. The unequal distribution of material wealth in Muara Nayan is mainly due to different education and (partly consequential) different income options. While people with a higher education can obtain stable and rather well paid jobs at the nearby oil palm and coal mining companies, people with low education can only work as daily wage labourers. Also among the wealthiest people in the village are the three families that each have a shop. They not only supply the villagers with their daily needs, but also profited from the increased transit traffic, as Muara Nayan is located on the main road connecting Samarinda with Sendawar. After decentralisation, more people became involved in illegal logging, although most logging activities were carried out in the areas of the surrounding villages as not much forest is left in Muara Nayan. The improved options to become involved in (illegal) logging were appreciated as additional income source by most people in Muara Nayan, but it was not perceived as a new income source as the area has a long history of logging activities.

Knowledge: The education level in Muara Nayan was higher than that in Jontai, but with only $45 \%$ of the households having a member with an education higher than middle school it was still generally low, especially among the grandparent and parent generations. This can be largely explained by the limited accessibility of education services. There was still no school in Muara Nayan. Children visit the primary school in nearby Lempunah and then continue middle and high school in Tanjung Isuy (the subdistrict capital) or Tenggarong (the district capital of the neighbouring district Kutai Kertanegara). Although school fees have been largely abolished, families still face difficulties in paying for accommodation, food and schooling materials for their children. However, school attendance increased with the increasing availability of education facilities and further support through (e.g.) the temporary open middle school in Lempunah and several scholarship programmes of local governments and NGOs. With increasing school attendance, the importance of formal knowledge also increased, while (similar to Engkuni Pasek) knowledge about adat, medicinal plants and traditional farming techniques was disappearing as children increasingly complete their education outside the village.

Natural sphere: The quality and the size of the forest in Muara Nayan decreased severely from the mid-1990s through forest fires, logging activities and land clearing for the oil palm plantation. People reported that forest fires occurred more often, due to prolonged draughts as well as the advanced state of forest degradation. The quality of the river water was declining through increasing pollution (see above). It had also become more difficult to catch fish in the local rivers, which I assume was also due to the general increase in water pollution and to unsustainable fishing practices.

Economic sphere: Since the 1980s, most households in Muara Nayan have experienced a 
severe loss of natural assets. Many rattan, rubber and forest gardens were burnt during the forest fires in 1982/83 and 1997/98. Additionally, many rattan, rubber and forest gardens were lost through the land clearing for the oil palm plantation, which was closely linked to the fires in autumn 1997 and spring 1998 (for a detailed analysis of the causes and impacts of the fires see Gönner 2000). The company opened their nursery only $2 \mathrm{~km}$ away from the village centre of Muara Nayan, which led to the loss of many fields and gardens close to the settlement. Many people expressed their frustration, as most villagers still had not received proper compensation for their loss. As the coal mining company is not operating within the village area, people of Muara Nayan did not receive compensation payments from the coal mining company and were not included in the companies' village development programmes. This angered many villagers, as they do suffer from the pollution caused by upstream mining activities. With the degradation of their natural assets, options for people in Muara Nayan declined, while their market dependency increased. In 2004, for example, no household was self sufficient in rice. With improved road conditions, the availability of goods increased as more traders started to stop in Muara Nayan, on their way to Sendawar. Some families could also profit from the increasing rubber prices, but only to a limited degree compared to
Engkuni Pasek, as many productive rubber trees had been damaged by fire. Motivated by the increasing rubber prices, however, people were continuing to plant new rubber gardens. Through the founding of a credit union by the NGO Puti Jaji, the number of households with savings increased during my stay in the village. All in all, most informants stated that their living standard was decreasing, as their living costs were continually increasing, while the options to generate income became more and more limited.

Social sphere: In Muara Nayan, solidarity is still strong in emergency cases and for the performance of rituals, while it is declining for collective action and for economic work. People explained that this is mainly caused by the decreasing number and size of rice fields in the village. The number of conflicts within the village as well as with the neighbouring villages had increased, mainly due to conflicting land rights claims and the unequal distribution of compensation payments from the oil palm and coal mining companies. However, in contrast to Engkuni Pasek and Jontai where the amount of conflicts increased sharply after decentralisation, the conflicts in Muara Nayan and the surrounding villages date back to 1996 when the oil palm company started to clear land for the plantation (see Box 6).

In July 1999, people in Muara Nayan conducted a large purification ritual to ease the situation. The

\section{Box 6. Day labourers on their own lands.}

In 1996, the oil palm company started land clearance activities in Muara Nayan and the surrounding villages. The company promised high incomes, modernisation and a plantation scheme that would include plots owned and farmed by the villagers. In 1997, some 16500 ha of former forest gardens and swidden fallows had already been cleared. Conflicts arose about compensation payments, as well as between the proponents and opponents of the oil palm plantation. In autumn 1997, forest fires started and raged again in spring 1998, partly intensified by fires started by villagers as a means of heightening the conflicts over land and compensation payments. In November 1998, people from nine villages occupied two of the company's three base camps demanding just compensation payments and an end to further expansion of the estate. In April 1999, the base camps were taken back by force by the police and several villagers were arrested. The villagers were released in October 1999, as the company was found to have no valid operation documents (Gönner 2002, pp. 84f). 


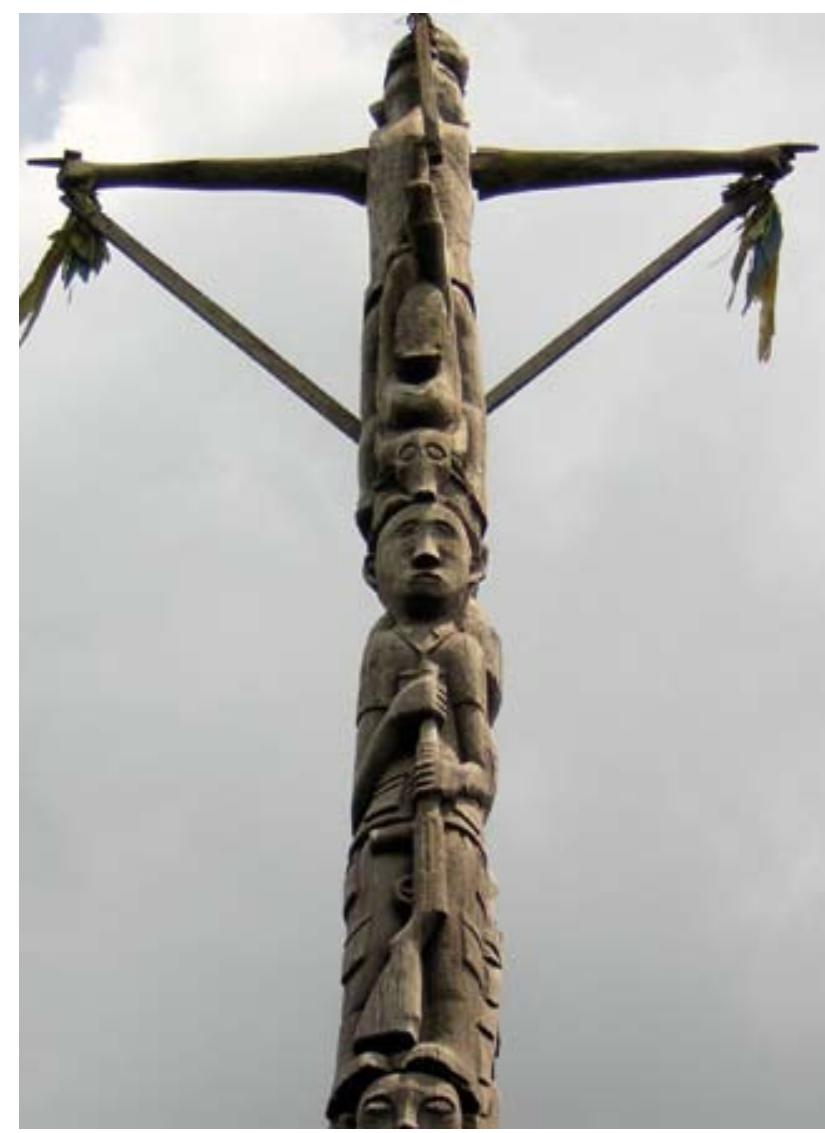

Picture 12: Pole (blontaakng) in Muara Nayan

unusually shaped pole (blontaakng) remains as a memorial to this. After the escalation of the conflict, the company stopped operations for some time. With decentralisation, they returned and finally in 2003 they received the proper operation documents. Although the situation has calmed down since the purification ritual, the tension is still felt among the villagers and the company. People complain bitterly that they now work as daily wage labourers on their own land, while no oil palm plots have been established for the villagers and most of them have not received proper compensation.

In comparison to Engkuni Pasek and Jontai, where adat rituals are performed frequently, the number of adat ceremonies seems to have declined in Muara Nayan. This might be explained by the death of an important shaman, as well as the increasing influence of protestant churches which denigrate adat rituals as evil practices.

Political sphere: The people in Muara Nayan reported a generally increasing political participation

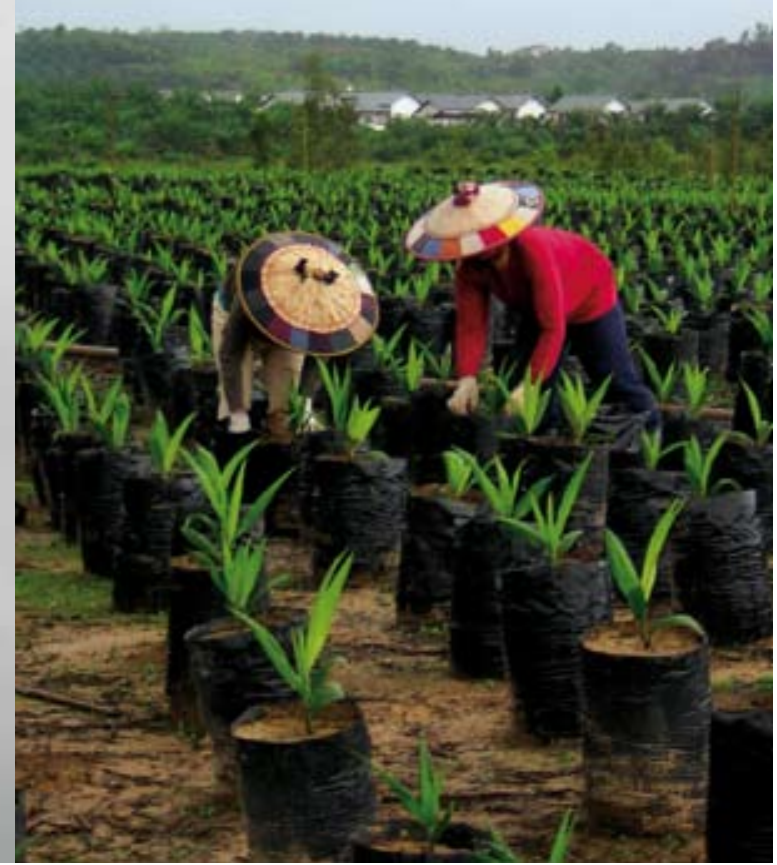

Picture 13:Working on the oil palm plantation

and self-determination, as more projects and meetings were carried out in the village than before decentralisation. The founding of the BPK improved participation in the village as people took the opportunity to work out some village regulations and get more actively involved in village politics.

Through the increasing value of land and the conflicts over compensation payments, land rights have become stricter in Muara Nayan. Areas owned together by a descent group (rempuuq) have caused much trouble, as the owners often fought about the distribution of compensation payments or their contradicting opinions about what to do with the respective field or garden (surrender it to the oil palm company or not). Due to the many problems they experienced with rempuuq, people in Muara Nayan tend to favour individual ownership rights. Traditional conflict resolution mechanisms have been experiencing increasing difficulties in handling conflicts over natural resources, especially those that involve the companies. People in Muara Nayan 
were disappointed by the local government as they have not felt supported well by it. A good example is the local government act SK Bupati Kutai Barat No.S90/K43/2003, which determined standard compensation payment prices for land, plants and trees within the district. Although the act was passed in February 2003, people in Muara Nayan did not know about it until late 2004, although it would have been of great importance for them in their continuing discussions with the oil palm company over compensation payments for the land taken in 1996/97. Furthermore, they felt disappointed that local government was not taking more severe steps to control the pollution in their village area.

Infrastructure and services: The road infrastructure in and around Muara Nayan increased with the improvement of the main road connecting Sendawar with Samarinda, as well as through the construction of new roads between the neighbouring villages. With the increasing road construction, water transportation declined. However, one could easily observe a difference in quality between the roads constructed close to the district centre and the roads constructed further from it (see Box 7). Health services improved with the founding of a Posyandu in Muara Nayan in 2004 and the introduction of Askes Gakin. Information structures improved with the availability of mobile phone signal at some spots in the village. During the previous 5 years, two new protestant churches started to offer their services in Muara Nayan. Due to positive experiences with local government officials in relation to development programmes carried out in the village (see Table 4), the relations with local government were generally valued as improved, despite the expressed disappointment about the lack of political support against the companies.

\section{Box 7. Destination determines the road quality.}

Despite an equal budget of almost Rp 1 billion (US\$ 110000 [2004]) per kilometre, the quality of road constructions within the district varied greatly. While the road from Muara Nayan to the subdistrict capital Tanjung Isuy was implemented so poorly in September 2004 that it could no longer be passed by motorbikes only 6 months later (left picture), the road from Sendawar to Dempar, which was also constructed in 2004, remained in good condition. Most people assume that this is due to the fact that the father of former district leader Rama Asia comes from Dempar.

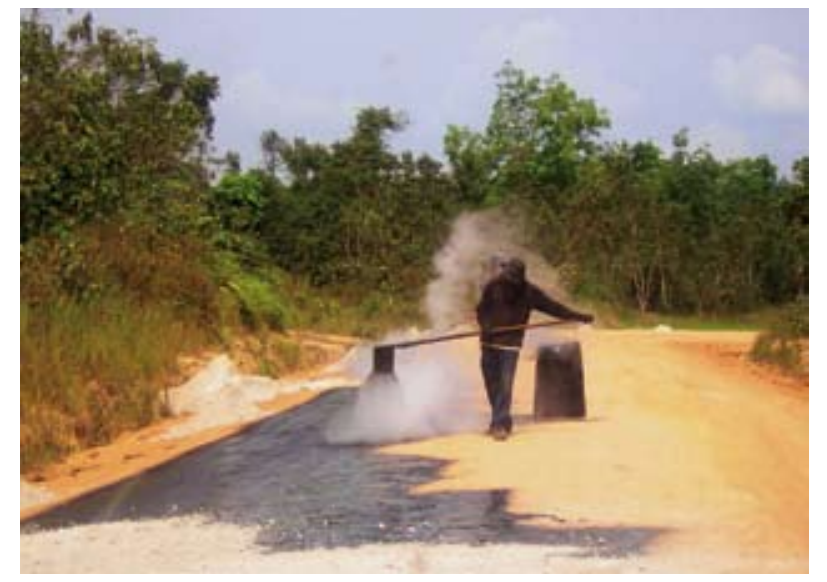

Picture 14: Road from Muara Nayan to Tanjung Isuy, September 2004 Picture 15: Road from Sendawar to Dempar, January 2005

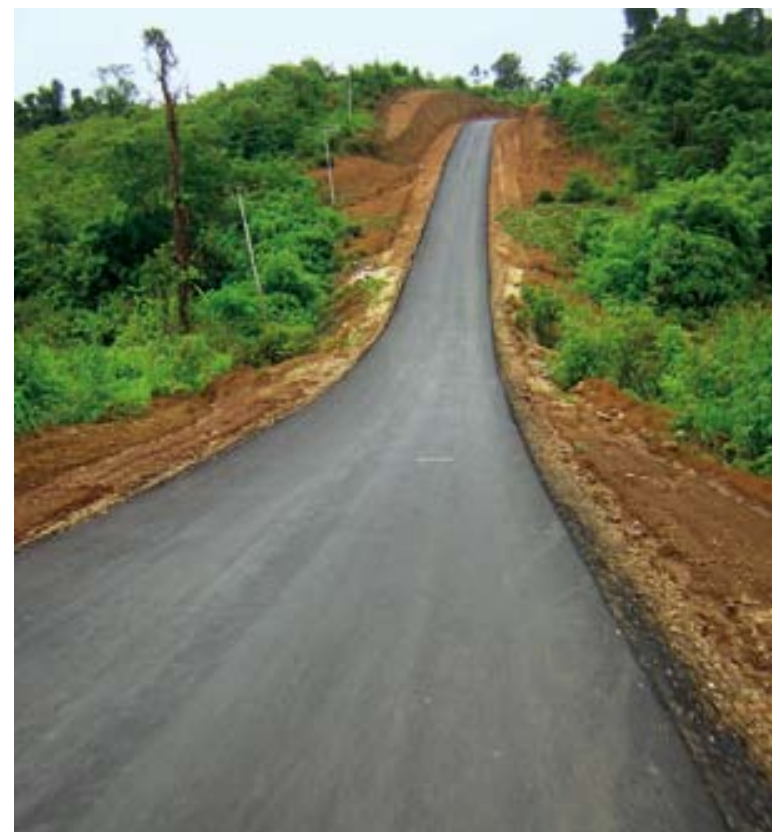


Table 4. Help programmes in Muara Nayan between 1999 and 2004.

\begin{tabular}{ll}
\hline Programme & Institution \\
\hline Reforestation Programme & $\begin{array}{l}\text { Local Government } \\
\text { (Dinas Kehutanan) } \\
\text { Local Government } \\
\text { (Dinas Pertanian) } \\
\text { Cattle Programme }\end{array}$ \\
$\begin{array}{l}\text { Local Government } \\
\text { (DPM) }\end{array}$ \\
Program to improve poor-quality housing & Local Government \\
Support to drill a well & (DPM) \\
& Local Government \\
Subsidised rice (Beras Miskin) & (SoSek) \\
& PT Askes and \\
Subsidised Health Insurance (Askes Gakin) & Local Government (SoSek) \\
& Puti Jaji \\
Establishment of a Credit Union & Puti Jaji \\
Workshop to empower village institutions and advise on & \\
establishment of village regulations & CARE Indonesia \\
Rice donation for the Posyandu & \\
\hline
\end{tabular}

Figure 12. Summarised wellbeing trends of Muara Nayan.

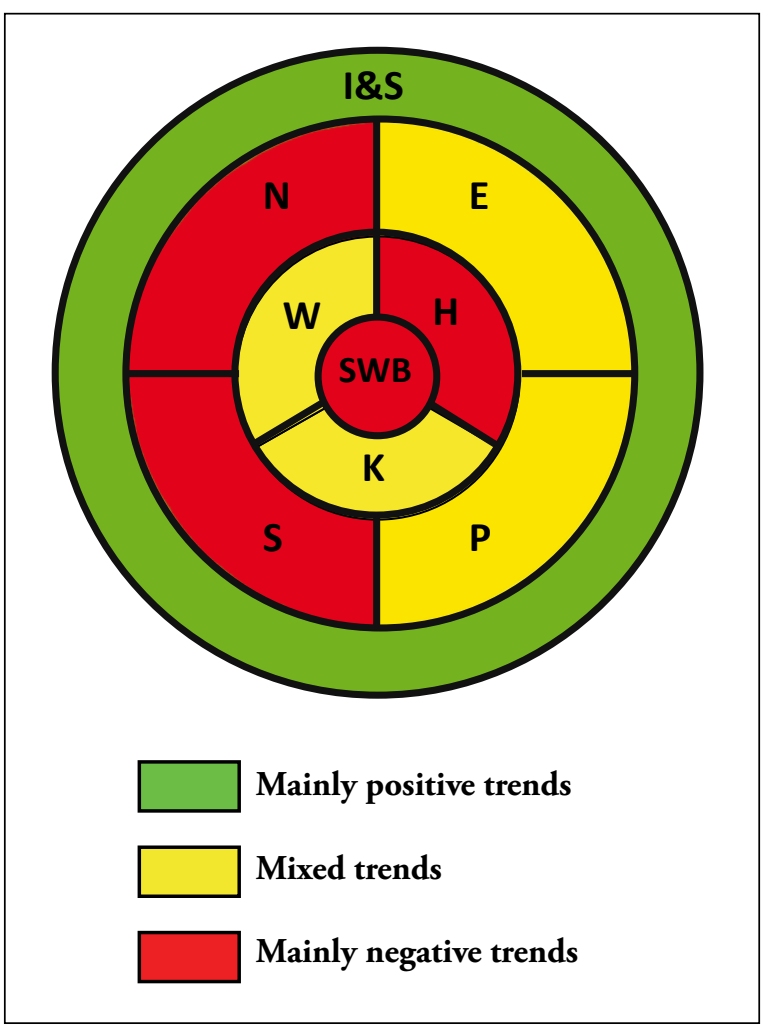

The coloured NESP model (Fig. 12) summarises the wellbeing trends in Muara Nayan based on the changes that I observed in the village.

\subsection{Common and Different Trends}

To understand the causal relations that lie behind the changes in Engkuni Pasek, Jontai and Muara Nayan, it is useful to distinguish between the changes that took place in all three villages and those that were only experienced in one or two of them. The common trends occurring in all three villages are summarised Table 5.

Major causes for these common trends are the formation of the new district of Kutai Barat and new subdistricts. The decentralisation laws, the legal vacuum created by decentralisation and new acts passed by local government (e.g. the HPHH regulation) are further major causes of these changes, as they were the key factors behind the logging boom in Kutai Barat. The activities of local government also triggered many changes-for example, the newly built roads contribute to illegal logging, as well as improving the availability of goods in the villages. Another important role is played by the private sector, as companies and their practices have a strong influence on conflicts among and between villages and are a major cause of the increasing pollution in Kutai Barat. The villagers themselves are a major trigger for change as well, as their desire 
Table 5. Common trends in all three villages.

\begin{tabular}{|c|c|}
\hline SWB & No common trends \\
\hline Health & Variety of food increased \\
\hline Wealth & $\begin{array}{l}\text { Material wealth increased } \\
\text { Inequality increased }\end{array}$ \\
\hline Knowledge & Importance of formal education increased \\
\hline Social sphere & $\begin{array}{l}\text { Conflicts over natural resources increased } \\
\text { Increased individualisation } \\
\text { Solidarity for common work is declining }\end{array}$ \\
\hline Economic sphere & Availability of goods increased \\
\hline Political sphere & $\begin{array}{l}\text { Traditional conflict resolution mechanisms face difficulties } \\
\text { Political participation and self-determination increased } \\
\text { Trend towards individual ownership of natural resources Relations with } \\
\text { local government increased }\end{array}$ \\
\hline Natural sphere & $\begin{array}{l}\text { Quality and size of forest declined } \\
\text { Quality of river water declined }\end{array}$ \\
\hline Infrastructure \& services & $\begin{array}{l}\text { Transportation infrastructure increased } \\
\text { Communication facilities improved } \\
\text { Health services increased }\end{array}$ \\
\hline
\end{tabular}

for a 'modern' lifestyle strongly influences their actions. The increasing value of natural resources is a further key factor, which itself is caused by a variety of reasons, one of them being the increasing inflow of companies into the district. And last but not least, natural hazards like droughts and forest fires have major impacts on peoples' livelihoods.

This shows that decentralisation is among the major causes for the recent changes, but it is not alone. Market dynamics within the timber, coal mining and oil palm sectors, companies' environmental policies and their attitude towards the local population, as well as natural hazards and the motivations of the local people themselves are also important and interwoven with each other.

Analysis of the trends reveals insights about the factors that influence the changes which are taking place in the villages as well as the impacts of decentralisation. New income sources opened up in Engkuni Pasek and Jontai, but not in Muara Nayan. People in Engkuni were the only ones from the three villages that could profit from the new jobs available within local government, as they were close enough and had the necessary high level of formal education. People in Engkuni Pasek profited most from the increased rubber prices as the majority of them had productive rubber gardens, while people in Jontai did not yet have many productive rubber trees and people in Muara Nayan did not have them anymore. The option to apply for a HPHH concession was only possible in Jontai, as the other two villages did not have enough forest left. People from all three villages got involved in (illegal) logging, but while this was perceived as a new income option in Engkuni Pasek and Jontai, is was not in Muara Nayan (as that village had a history of logging). House building activities increased mainly in Engkuni Pasek and Jontai, where people had higher cash incomes and better access building material. Market dependency increased most in Engkuni Pasek and Muara Nayan, where hardly any household was self sufficient in rice. Better savings options arose in Engkuni Pasek and Muara Nayan due to NGO efforts, which had not taken place in Jontai. Traditional knowledge had already declined more in Engkuni Pasek and Muara Nayan, while it was still strong in Jontai. Noble (mantiiq) descent still played an important role in Jontai, where it still determined leadership positions and local power relations, while it seemed to be of no importance in Engkuni Pasek and Muara Nayan. This can be explained with the, until recently, rather isolated location of Jontai, which preserved a more 
traditional lifestyle. Although people in all three villages stated that the help they received from local government increased compared to before decentralisation, the amount of the received help documents how development efforts varied with physical and personal distance from the district and the district leader (see Tables 2, 3 and 4). This led to the great differences among the villages in the perception of decentralisation.

This shows that the effects of decentralisation and the recent processes of change do not proceed in a consistent pattern, but depend on the availability, distribution and management of new income sources, the size and quality of the village forest, the availability of resources, the level of education, the physical and personal distance from the district capital and the district head, on the kinds of private sector and NGO activities and, last but not least, the level of modernity in lifestyle.

\subsection{Most Recent Changes}

Commodity prices increased sharply after the fuel subsidies stopped in October 2005 and the new forest policies drew back authority to central government and intensified the control of illegal logging. One year after my first household survey, I revisited the villages and conducted a second household survey to determine the impacts of these recent policy changes.

When I asked the people to compare their economic situation at the end of 2005 with that of 2004, some $31 \%$ of the households in Engkuni Pasek said that their situation had worsened, while $24 \%$ said it had remained stable, and $45 \%$ stated that it had further improved. Major reasons for the decrease were the complete stop of (illegal) logging due to strict controls, and the increasing prices that followed the ending of fuel subsidies. The households that reported an improved situation were those with large productive rubber gardens, as they profited from the further increasing rubber prices. ${ }^{21}$ The families that reported a stable income were mainly those that received a salary, e.g. as teacher or local government official. People in Engkuni Pasek suffered from the lost cash income through (illegal) logging, as many people had to return motorbikes, which they had bought on credit. However, salaries and rubber tapping remained as reasonably stable income sources. Most people thus shifted from timber to rubber and those who did not have many rubber gardens eagerly started to plant rubber trees anticipating continuing strong rubber prices.

People in Jontai suffered most from the policy changes: $52 \%$ of the households reported a decline of their household economy compared to 2004, while only $28 \%$ reported an improved situation. The most important reason for the decline was the lost income from logging, due to strict controls in the village area. The income from fee payments had declined as well, as people lost their bargaining power as soon as the licences were again issued from the centre directly to the companies. For some families, fee payments had also stopped because their location had been logged out. The positive effect of the declining fee payments was that the number of conflicts within the village declined. However, most villagers felt very disappointed about the recent policy changes and compared them to situation under the Orde Baru, when they weren't allowed to cut timber in their traditionally owned forest. Most households lacked alternative income options, while the rising prices further increased their living costs. As in Engkuni Pasek, some people had to hand back items bought on credit or sell gold jewellery in order to make ends meet. Households that reported an improving economic situation provided different reasons, such as their improved housing condition, their well-running kiosk or the luck to have found a new husband. Most households in Jontai shifted back to subsistence strategies, combined with daily wage labour and rattan as sources for additional cash income. However, in comparison to (illegal) logging, cutting and selling rattan was perceived as hard and unsatisfying work, as rattan prices remained low. ${ }^{22}$ 
People thus started to express hopes for the soon opening of a coal mine in their area, so they could profit from compensation payments.

In Muara Nayan, $54 \%$ of the households stated that their economic situation had remained the same compared to 2004 , while $14 \%$ reported an improved and 32\% a declined situation. As major reasons for the decline, people mentioned increased commodity prices as well as the decline in income from timber. The (illegal) logging activities had not come to a total stop around Muara Nayan, as they had in the vicinity of Sendawar, as the controls have been mainly focused around the centre of Kutai Barat. Among the people that reported an improved situation was a family that had renovated their house and the two shopkeepers of Muara Nayan who had been able to enlarge their businesses. With the decreasing income from timber, the most important income source for people in Muara Nayan became daily wage labour on the oil palm plantation, which further increased their dependency on the oil palm company.

All in all, the ending of fuel subsidies led to a large increase of living costs in Kutai Barat, where prices had already been high due to the remoteness of the district. The direct cash help (BTL) of Rp 100000 (US\$ 10 [2005]) per month, which was paid to poor families in order to compensate for the increased prices, was far from balancing the increased living costs in Kutai Barat, where transportation costs nearly doubled. People in all three villages expressed their dislike of the BTL payment. They would have preferred support in the form of increased education and health facilities. Due to the low purchasing power of Rp 100000 (US\$ 10 [2005]) in Kutai Barat, no scenes appeared like those reported from Java where people fought over the cash help. For example, one man told me that his transportation costs to pick up the money were higher than the actual BTL payment.

The policy changes within the forestry sector were felt strongly in all three villages. Through the strict control of illegal logging, one of the most important income sources during 2004 was lost or at least severely reduced. After the recentralisation of authority to central government, logging companies again received their concession licences (IUPHHK) directly from the Ministry of Forestry. Thus, they were no longer the contractors of the villagers, as they were under the $\mathrm{HPHH}$ regulation. This changed position immediately led to a decline in fee payments, as the bargaining power of the villagers was lost. Fees in Jontai rose from Rp 3000 (US\$ 0.36 [1999]) per $\mathrm{m}^{3}$ under the previous $\mathrm{HPH}$ system to Rp 65000 (US\$ 7.15 [2004]) per $\mathrm{m}^{3}$ under the HPHH regulation. Under the IUPHHK, they fell again and have subsequently (2005-2007) varied between Rp 25000 (US\$ 2.75 [2007]) and Rp 45000 (US\$ 4.95 [2007]) per $\mathrm{m}^{3}$, depending on personal bargaining abilities and the location of the respective forest plot. All in all, the new forest policies weakened the position of local communities and deprived them of lucrative income sources, while it enabled the timber companies to change their licence and just continue working.

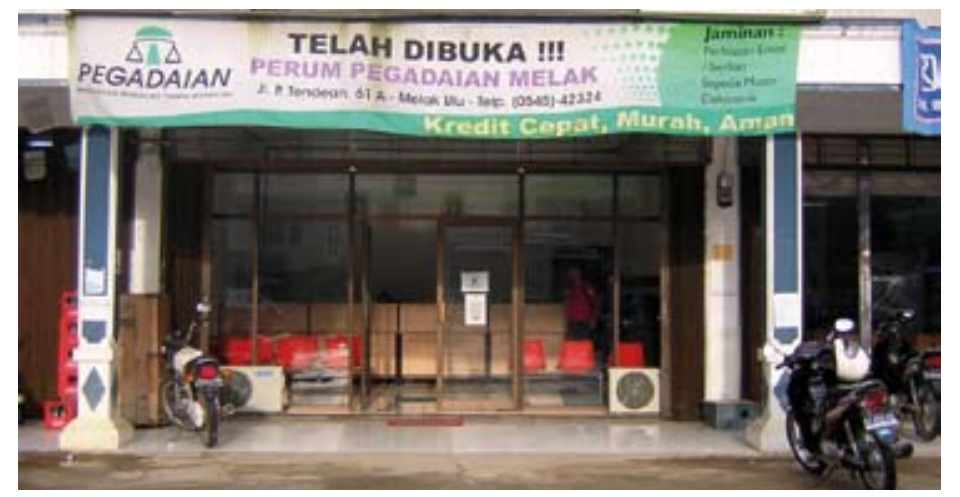





\section{Conclusions}

\section{How do the Dayak Benuaq perceive poverty?}

The Dayak Benuaq distinguish between a common understanding of poverty-which in a rather narrow sense is based on material deprivation-and the concept of a good life (bolupm bueq) and a bad life (bolupm daat), comprising a broad variety of economic, social, political and emotional aspects. Inquiries into the most important wellbeing aspects showed that the fulfilment of 'basic needs', an economically secure livelihood and good social relations lie at the heart of Dayak Benuaq wellbeing. What is considered to be most important for one's own wellbeing varies little between men and women and only slightly among different age groups. Subjective wellbeing differed between the villages and also slightly by gender, as women reported a higher subjective wellbeing than men. The largest differences in subjective wellbeing were found by age, with old people tending to experience a lower subjective wellbeing than young people. The indigenous concept of the Dayak Benuaq seems very similar to the concept of wellbeing and illbeing, and affirms the initial argument that assessing poverty in terms of wellbeing and illbeing is useful and congruent with peoples' own aspirations.

\section{How did decentralisation impact Dayak Benuaq wellbeing?}

Decentralisation had positive and negative impacts on Dayak Benuaq livelihoods. The creation of the new district improved the political participation and self-determination of the formerly marginalised Dayak population and led to a rise of new Dayak elites. Infrastructure and government services improved in many areas-main examples being the new government buildings and several new roads, as well as improvements in health and education services. Local government's poverty alleviation programmes were visible in the villages, but they often lagged behind the expectations of both local government officials and the villagers, due to poor implementation and weak control mechanisms. The general development of the district has been concentrated around the centre of the new district and thereby disappointed many people living in more remote subdistricts.

Decentralisation opened up several new economic opportunities: (illegal) logging, fee and compensation payments provided temporarily high cash incomes, which mainly led to a short-lived increase in material wealth, as only a few families used the money to secure their livelihoods through long-term investments. New job opportunities within local government and increasing rubber prices provided new-though not as profitable, but much more stable-income sources. As people profited differently from the new economic opportunities and also handled their profits differently, inequality within the villages increased sharply. Conflicts among villagers and also between villagers and companies have increased since decentralisation. Most conflicts were caused by unequal distributions of benefits and contradicting claims over land and natural resources, which both increased 
in value. Many conflicts were further complicated through the growing tendency towards individual ownership and weakening traditional conflict resolution mechanisms.

Decentralisation led to an increase in extractive resource use, such as logging and coal mining, which reduced the size and the quality of the forest in Kutai Barat and increased pollution. Over the long term, this will further lead to a loss of alternative livelihood strategies and increase market dependency. The lax control of timber, mining and oil palm companies through local government further added to their negative impact on the natural and social environments. After the ending of fuel subsidies and recent policy changes in the forestry sector, the economic situation of most households worsened. While people in Engkuni Pasek and Jontai fall drop back on alternative livelihood strategies, people in Muara Nayan depended on the oil palm company even more than before.

All in all, decentralisation generated a variety of new opportunities, but with high costs in the social and natural environments. The unbalanced use of new political and economic opportunities and the extractive use of natural resources increased the vulnerability of Dayak Benuaq livelihoods and put environmental and social sustainability at risk. The coloured NESP model (Fig. 13) summarises the aggregated wellbeing trends for Kutai Barat, based on the changes that I observed during my field research.

\section{How can poverty and wellbeing be measured in a comprehensive manner?}

It has been fruitful to work with a broad poverty concept, which in this case proved to be congruent with the Dayak Benuaq's indigenous perception. The NESP model has provided a useful frame to assess changes in local wellbeing. Thus, it stands out from the Sustainable Livelihood Approach (SLA) and the closely related five capital approach, which
Figure 13. Aggregated wellbeing trends for Kutai Barat.

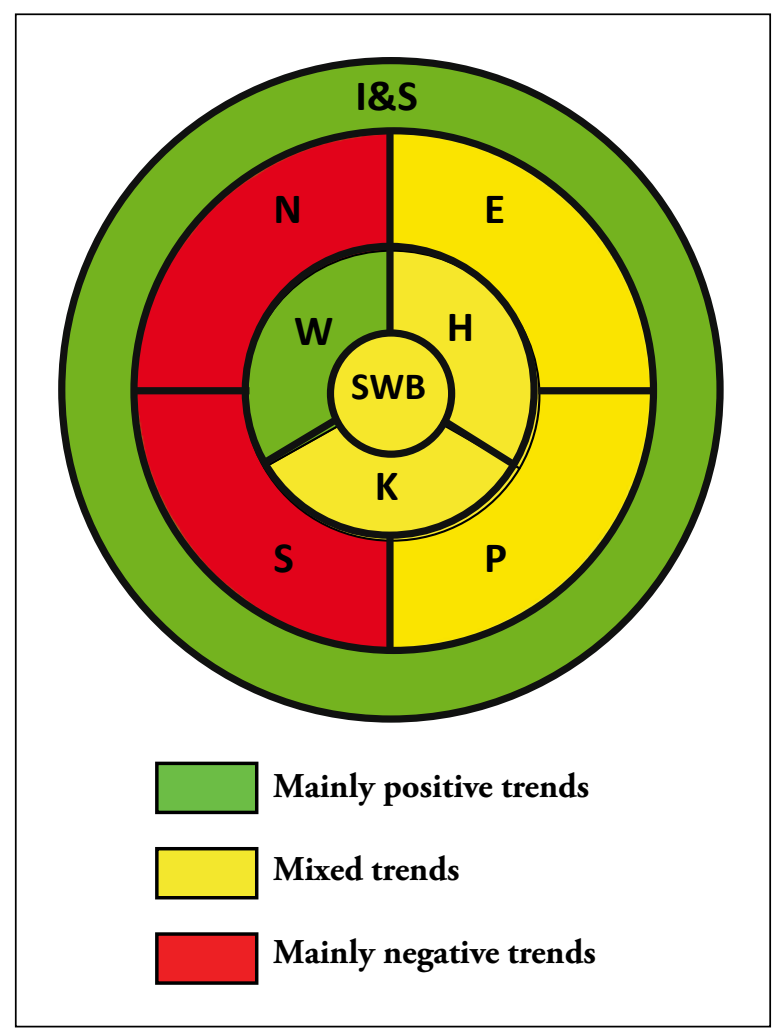

are suitable tools to assess peoples' strengths but are difficult to use as frameworks for analysing ongoing processes. The NESP model has shown that it can be used as a tool to measure the multidimensionality of poverty with quantifiable indicators (Gönner $e t$ al. 2007a), as well as a framework for qualitative wellbeing analysis. With its multiple spheres, the model demonstrates the complexity of poverty and trade-offs. Itcan thuscomprehensibly mirror a current state of wellbeing or visualise observed wellbeing trends, but it cannot reflect the causal relations and interrelationships among and within the spheres. The holistic approach of cultural anthropology and its classic method of participant observation provided deep insights into the complex causal relations, the motivations and intentions of different actors, and the intertwinement of decentralisation with other processes of cultural change. Many of these insights contributed to the development and refinement of the NESP model. Cultural anthropology has much to offer to poverty research, by assessing indigenous 
perceptions of poverty, gaining detailed insights into interrelationships at the micro-level, and contributing to the development of concepts and models of poverty.

\section{How does decentralisation influence poverty?}

Decentralisation is always intertwined with other factors and ongoing processes of social, economic and political change. In Kutai Barat, it is mainly mixed with the spirit of Reformasi and the current changes in Dayak Benuaq culture. In some parts, decentralisation is accelerating processes of changefor example, the rising value of natural resources further increased the individualisation of resource rights. However, decentralisation does not influence all aspects that are related to poverty and cannot be seen as automatically propoor. Rather, it sets a new frame in which the actors and their respective power relations determine who benefits and who does not. In this way, decentralisation can be viewed as some new rules of the game, which are then interpreted, used, circumvented and redefined by the local players as they interact. Laws constitute the rules of the game. But people create their own rules, cheat them and play with them, and by this determine outcomes of decentralisation. Decentralisation is therefore a dynamic process with short- and longterm impacts, which are difficult to avoid and always have to be addressed and understood in context. Future research on poverty and decentralisation should thus try to understand the motivations, networks, power plays, interest groups, and informal decision making processes. 


\section{Recommendations}

After demonstrating the positive and negative impacts that decentralisation had on Dayak Benuaq wellbeing and providing insights into the causal relations and trade-offs among the recent trends, the question arises: what could be done to reduce the negative impacts and strengthen the positive developments? Our project team has worked out a number of general recommendations, as well as some very specific methodological and practiceoriented suggestions for the improvement of poverty monitoring and the implementation of poverty alleviation strategies in Kutai Barat (Andrianto 2006; Cahyat et al. 2007; CIFOR 2007; Gönner et al. 2007a, b).

The chances of overcoming poverty and improving wellbeing depend largely on the enabling environment. To increase wellbeing in Kutai Barat, the capabilities of the poor should be utilised and strengthened. Therefore, local government should assess existing local livelihood strategies and ensure that alternative livelihood strategies do not get lost through unsustainable practices. Furthermore, it should create an institutional framework that supports sustainable self-driven strategies for improving wellbeing. The villagers in Kutai Barat need economic opportunities, such as jobs and markets, but they also need political opportunities in order to actively participate in local decision making. Local governments, working together with other levels of government and the private sector, have a clear role in providing these kinds of opportunities. They are also obliged to control the private sector and enforce the legal environmental and social obligations of companies in order to minimise their negative impact on the environment and to maximise their benefits for the population. In addition, vulnerability needs to be reduced. This can be achieved through public safety net functions like free health insurance, free education and subsidised food, but also through private measures and traditional institutions, such as family- or communitybased safety nets. Economic vulnerability can be reduced by income diversification and a broad portfolio of alternative livelihood strategies. These, however, depend heavily on the quality of the natural environment. Finally, sustainability is required to ensure the longterm stability and improvement of local wellbeing. Sacrificing the environment or social cohesion for economic short-term gains does not improve wellbeing. Being aware of and balancing the trade-offs among the different aspects of wellbeing is of major importance, although is provides a great challenge for all decision makers in Kutai Barat.

Key recommendations for the local government in Kutai Barat to improve wellbeing under decentralisation include the following (Gönner et al. 2007b). 


\section{Improve monitoring and planning}

- Gain a better understanding of poverty in Kutai Barat (who are the poor, how poor are they, where do they live and why are they poor, what can be done and how do these facts change over time?)

- Facilitate community development planning

- Develop more participative planning processes.

\section{Improve services and infrastructure}

- Improve extension services (community forestry, agriculture, manufacturing)

- Provide more capacity building (e.g. training courses) within the communities

- Increase number and quality of teachers and open middle schools (SLTP)

- Increase number and quality of health staff and facilities

- Create better incentives for qualified health and education staff to work in remote areas

- Monitor presence and quality of education and health staff

- Improve access to remote communities, especially in the upper Mahakam and in Bentian Besar

- Improve economic infrastructure (roads and bridges, energy supply, communication)

- Improve vocational education.

\section{Maintain subsidiary system}

- Continue free health care (Askes Gakin) for the poor

- Continue subsidised rice programme (Raskin)

- Continue free schooling, include high schools (SLTA)

- Maintain subsidised flights to Hulu Riam.

\section{Improve natural sphere}

- Provide and enforce legal frame for sustainable forest resource use, including community-based natural resource and forest management

- Support conservation efforts
- Set incentives for reforestation efforts

- Mediate conflict between customary and legal resource access rules

- Enforce legal obligations of companies (concerning communities and the environment and pollution).

\section{Improve economic sphere}

- Create a stable enabling environment for economic development

- Attract investors

- Support local entrepreneurs, e.g. through favourable taxation during start-up phase

- Establish a minimum wage for company employees to combat debt problems

- Establish and enforce labour safety regulations and basic health requirements for workers

- Support small and medium-sized enterprises (e.g. through start-up services including reduced taxes)

- Strengthen financial management skills of local people

- Assess and support sustainable local livelihood strategies, e.g. extended subsistence systems based on cultivation of upland rice and off-farm income generation

- Facilitate access to capital and markets, also through further expansion of credit unions.

\section{Improve social sphere}

- Identify and communicate with relevant social groups

- Offer mediation for conflicts and disputes between villages, and between villages and enterprises

- Encourage social cohesion

- Promote collaboration among local interest groups

- Distribute amount and quality of development more equally. 


\section{Improve political sphere}

- Empower villages and vulnerable/marginalised groups through more participation

- Establish genuine two-way communication with the poor

- Increase accountability of subdistrict and village leaders towards their constituents

- Provide and enforce legal protection and security

- Strengthen traditional land and resource use rights

- Increase transparency and fight corruption. 


\section{Endnotes}

1 'We' refers to the entire CIFOR-BMZ Project Team.

${ }^{2}$ Exceptions from this trend are the works of Oscar Lewis (e.g. 1971, 1996) and the subfields of action anthropology and urban anthropology, with the latter being especially strong in the USA (Curtis 1999; Susser 1996). However, their efforts have not (yet) had any strong influence on the overall rejection of 'poverty' within the discipline.

${ }^{3}$ Comprising social scientists, cultural anthropologists, foresters and economists.

4 These include the Central Statistics Agency (BPS), the former National Family Planning Agency (BKKBN), the Programme on Compensation for Reduced Petroleum Fuel Subsidies (PKPS-BBM), the Self-sufficiency movement Gerakan Sendawar Makmur (GSM) and the UNDP Human Development Index (HDI) and Human Poverty Index (HPI).

5 The different spheres constitute an analytical effort to cut the complexity of life into accessible pieces and should not be viewed as an impermeable division as the aspects of the various spheres do influence each other.

${ }^{6}$ My research was split into three stays: from February 2004 to February 2005, March 2005 to June 2005 and October 2005 to March 2006, each being equally split among the three research locations.

${ }^{7}$ For a description of the villages and their selection criteria see section 2.1 .

${ }^{8}$ This comprised 120 people in Engkuni Pasek, 120 in Jontai and 60 in Muara Nayan, with equal proportions of young people, parents and grandparents generations, as well as equal proportions of men and women.

${ }^{9}$ This comprised 120 people in Engkuni Pasek, 120 in Jontai and 60 in Muara Nayan, with equal proportions of young people, parent and grandparent generations, as well as equal proportions of men and women.

${ }^{10}$ This comprised 30 households in Engkuni Pasek, 30 in Jontai and 20 in Muara Nayan, representing a minimum of $50 \%$ of the households in each village.

${ }^{11}$ From Rp 372.4 billion (US\$ 37 billion [2001]) in 2001 to Rp 663.1 billion (US\$ 79 million [2003]) in 2003 (Andrianto 2006, p. 30).

${ }^{12}$ According to Weinstock (1983, p. 18) the term can be traced back to the word haring, which means 'self-existent', 'source' or 'vitality'. The affiliation with Kaharingan played a major role in the struggle for an independent Dayak Province, which led to the founding of Central Kalimantan in 1957.
${ }^{13}$ Most Indonesian statistics (e.g. BKKBN) count the number of families by kepala keluraga (shortened to 'kk') per village and not necessarily the number of households.

${ }^{14}$ Undang Undang tentang pemerintahan Desa UU No. 5/1979.

15 The BPK has been implemented according to the local regulation Peraturan Daerah Kabupaten Kutai Barat No. 17/ 2001 tentang Pembentukan Badan Perwakilan Kampung.

${ }^{16}$ People sometimes use the words tebeetn or kabeh for 'poor', but because their meaning differs from a rather economic understanding of being poor to a very broad one, I do not consider them as equivalent to 'miskin', but rather as describing the situation of a bad life (bolupm daat).

${ }^{17}$ In the Jempang area, language differs slightly and one also finds the term bolupm buatn. The concept of bolupm bueq is reminiscent of the Indonesian term kesejahteraan (prosperity). However, they cannot be seen as synonymous, because kesejahteran underlies the poverty concept used by BKKBN and is thus limited to certain aspects of socioeconomic wellbeing (Cahyat 2004).

${ }^{18}$ Many forest gardens in Muara Nayan were lost in forest fires and the opening of a palm oil plantation. In Jontai, people have many more rattan than rubber gardens. During my research time they suffered from low rattan prices.

19 This result comes very close to the result of the poverty monitoring conducted in all 223 villages of Kutai Barat by the CIFOR-BMZ project in 2006 , where $43.5 \%$ of the households report a poor SWB, 27.5\% an intermediate SWB and $29 \%$ a good SWB (Gönner et al. 2007b, p. 20).

${ }^{20}$ Rubber prices in Engkuni Pasek increased form Rp 300 (US\$ 0.13 [1996]) per kg before 1997 to Rp 3100 (US\$ 0.34 [2004]) per $\mathrm{kg}$ in 2004, and up to Rp 3700 (US\$ 0.37 [2005]) per kg in early 2005.

${ }^{21}$ In this report I use average conversion rates for each year (indicated in brackets) as follows: (1996): 0.00043 - US\$ 1 $=\mathrm{Rp} 2.328$; (1999): $0.00013-\mathrm{US} \$ 1=\mathrm{Rp} 7.879$; (2000): 0.00012 - US\$ 1 = Rp 8.412; (2001): 0,00010 - US\$ $1=$ Rp 10.250; (2003): 0.00012 - US\$ 1 = Rp 8.593; (2004): 0.00011 - US\$ 1 = Rp 8.945; (2005): $0.00010-$ US\$ $1=$ Rp 9.721; (2006): 0.00011 - US\$ 1 = Rp 9.184; (2007): 0.00011 - US\$ $1=\operatorname{Rp} 9.110$.

${ }^{22}$ Rubber prices had reached Rp 4200 (US\$ 0.42 [2005]) per $\mathrm{kg}$ by the end of 2005 and continued to climb further, as they were by Rp 5600 (US\$ 0.62 [2007]) per kg in mid-2007.

${ }^{23}$ Between 2004 and 2005, the prices for the rattan species sega remained stable in Jontai at Rp 800 (US\$ 0.09 [2004]) per $\mathrm{kg}$. 
Agrawal, A. 2000 The politics of decentralisation. A critical review. Welt Trends 25: 53-74.

Ahmad, J., Bird, R.M. and Litvack, J. 1998 Rethinking Decentralisation in Developing Countries. World Bank, Washington, DC.

Andrianto, A. 2006 The Role of District Government in Poverty Alleviation: Case Studies in Malinau and West Kutai Districts, East Kalimantan, Indonesia. CIFOR, Bogor, Indonesia.

Aspinall, E. and Fealy, G. (eds.) 2003 Local Power and Politics in Indonesia: Decentralisation and Democratisation. Institute for Southeast Asian Studies, Singapore.

Baumann, P. 2000 Sustainable livelihoods and political capital: arguments and evidence from decentralization and natural resource management in India. Sustainable Livelihoods Working Paper No. 136. Overseas Development Institute (ODI), London.

Barr, C., Resosudarmo, I.A.P., Dermawan, A. and McCarthy, J. 2006 Decentralisation of Forest Administration in Indonesia: Implications for Forest Sustainability, Economic Development and Community Livelihoods. CIFOR, Bogor.

Barr, C. and Resosudarmo, I.A.P. 2002 Decentralisation of Forest Administration in Indonesia: Implications for Forest Sustainability, Community Livelihoods, and Economic Fevelopment. CIFOR, Bogor.

Barr, C., Wollenberg, E., Limberg, G., Anau, N., Iwan, R., Made Sudana, I., Moeliono, M. and Djogo, T. 2001 The Impacts of Decentralisation on Forests and Forest-dependent Communities in Malinau District, East Kalimantan. CIFOR, Bogor.

Benda-Beckmann, F. von and Benda-Beckmann, K. von 2001 Recreating the Nagari: Decentralisation in West Sumatra. Working Paper No. 31. Max Planck Institute for Social Anthropology, Halle.

Bonoh, Y. 1982 Fungsi Patung-Patung Tradisional Suku Dayak Benuaq. Departemen Pendidikan dan Kebudayaan, Direktorat Jendral Kebudayaan and Museum Negeri Propinsi Kalimantan Timur Mularwarman, Samarinda, Indonesia.

Bonoh, Y. 1985a Lungun dan upacara adat. Departemen Pendidikan dan Kebudayaan
Propinsi Kalimantan Timur, Samarinda, Indonesia.

Bonoh, Y. 1985b Belian Bawo. Departemen Pendidikan dan Kebudayaan Propinsi Kalimantan Timur, Samarinda, Indonesia.

Breman, J. and Wiradi, G. 2002 Good Times and Bad Times in Rural Java. Case Study of SocioEconomic Dynamics in Two Villages toward the End of the Twentieth Century. KITLV Press, Leiden.

Brillantes, A.B. and Cuachon, N.G. 2002 Decentralisation and Power Shift: An Imperative for Good Governance: A Sourcebook on Decentralisation Experiences in Asia. Vol. 1. Centre for Local and Regional Governance Working Papers Series 2002/02. Asian Resource Centre for Decentralisation, Manila.

Cahyat, A. 2004 Bagaimana kemiskinan diukur? Beberapa Model Penghitungan Kemiskinan di Indonesia. Governance Brief No. 2. CIFOR, Bogor, Indonesia.

Cahyat, A, Iranon, B., Edna, B., Dalip, D., Tiaka, D., Haripuddin (Lado), Tugiono, K., Himang, M.G.D., Muksin, S., Supiansyah, Yohanis and Gönner, C. 2005 Profil Kampung-Kampung di Kabupaten Kutai Barat. Kondisi Sosial Ekonomi Kampung-kampung. CIFOR, Bogor, Indonesia.

Cahyat, A., Gönner, C. and Haug, M. 2007 Assessing Household Poverty and Wellbeing: A Manual with Examples from Kutai Barat, Indonesia. CIFOR, Bogor, Indonesia.

Casson, A. 2001 Decentralisation of Policies Affecting Forest and Estate Crops in Kutai Barat District, East Kalimantan. CIFOR, Bogor.

Center for International Forestry Research (CIFOR) 2007Towards Wellbeing in Forest Communities: A Source Book for Local Government. CIFOR, Bogor, Indonesia.

Chambers, R. and Conway, G.R. 1991 Sustainable Rural Livelihoods. Practical Concepts for the 21st Century. IDS Discussion Paper 296.

Cleary, M. and Eaton, P. 1992 Borneo: Change and Development. Oxford University Press, Singapore.

Crevello, S.M. 2003 Local Land Use on Borneo: Applications of Indigenous Knowledge Systems and Natural Resource Utilisation Among the 
Benuaq Dayak in East Kalimantan, Indonesia. Ph.D. Thesis, Louisiana State University.

Crook, R.C. and Manor, J. 1998 Democracy and Decentralisation in South Asia and West Africa: Participation, Accountability and Performance. Cambridge University Press, New York.

Crook, R.C. and Sverrison, A.S. 2001 Decentralisation and Poverty Alleviation in Developing Countries: A Comparative Analysis, or is West Bengal unique? IDS Working Paper 130. Institute for Development Studies (IDS), Brighton, UK.

Curtis, C.A. 1999 'Bottom-up' poverty and welfare policy discourse: ethnography to the rescue? Urban Anthropology 28(2): 103-140.

Devung, S. 1990 Upacara Tradisional „Kuangkay“ Suku Dayak Benua Daerah Kalimantan Timur. Departemen Pendidikan dan Kebudayaan Kanwil DEPDIKBUD Propinsi Kalimantan Barat.

Escobar, A. 1991 Anthropology and the development encounter: the making and marketing of development anthropology. American Ethnologist 18(4): 658-682.

Gönner, C. 2000 Causes and impacts of forest fires: a case study from East Kalimantan, Indonesia. International Forest Fire News 22: 35-40.

Gönner, C. 2001 Muster und Strategien der Ressourcennutzung: eine Fallstudie aus einem Dayak Benuaq Dorf in Ost Kalimantan, Indonesien. Forstwissenschaftliche Beiträge 24 der Professur Forstpolitik und Forstökonomie. Eidgenössische Technische Hochschule Zürich.

Gönner, C. 2002 A Forest Tribe of Borneo: Resource Use Among the Dayak Benuaq. D.K. Printworld, New Delhi.

Gönner, C. and Seeland, K. 2002 A close-to-nature forest economy adapted to a wider world: a case study of local forest management strategies in East Kalimantan, Indonesia. Journal of Sustainable Forestry 15(4): 1-26.

Gönner, C., Haug, M., Cahyat, A., Wollenberg, E., de Jong, W., Limberg, G., Cronkleton, P., Moeliono, M. and Becker, M. 2007a Capturing Nested Spheres of Poverty: A Model for Multidimensional Poverty Analysis and Monitoring. Occasional Paper 46. CIFOR, Bogor, Indonesia.

Gönner, C., Cahyat. A., Haug, M. and Limberg, G. 2007b Towards Wellbeing: Monitoring Poverty in Kutai Barat, Indonesia. CIFOR, Bogor, Indonesia.
Gunawan, R., Thamrin, J. and Suhendar, E. 1999 After the Rain Falls...: The Impacts of the East Kalimantan Forestry Industry on Tribal Society. Yayasab Akatiga, Bandung.

Harris, A.A. 2006 Besara: Tata Cara dan Sistem Peradilan Adat Masyarakat Dayak Benuaq Kalimantan Timur. Biro Humas Setdaprov Kaltim, Samarinda, Indonesia.

Haryo Widjono AMZ 1998 Masyarakat Menatap Hari Esok. Grasindo, Jakarta.

Haug, M. 2002 Ressourcenwahrnehmung und Bodenrecht der Dayak Benuaq in Ost Kalimantan, Indonesien: Ein Fallbeispiel aus Engkuni Pasek. M.A. Thesis, University of Cologne, Germany.

Haug, M. Forthcoming. Poverty and Change in East Kalimantan: The Impacts of Decentralisation on Dayak Benuaq Well-being and Livelihoods. Ph.D. Thesis (draft). Freiburg University, Germany.

Hopes, M. 1997 Ilmu: Magic and Divination amongst the Benuaq and Tunjung Dayak. Puspa Swara, Jakarta.

Hopes, M., Madrah, D. and Karaakng 1997 Temputn: Myths of the Benuaq and Tunjung Dayak. Puspa Swara, Jakarta.

Kanbur, R. and Squire, L. 2001 The evolution of thinking about poverty: exploring the contradictions. In: Meier, G. and Stiglitz, J. (eds.) Frontiers of Development Economics. Oxford University Press, Oxford.

Klinken, G. van. 2002 Indonesia's new ethnic elites. In: Nordholt, H.S. and Abdullah, I. (eds.) Indonesia: In Search of Transition. Pustaka Pelajar, Yogyakarta.

Kraienhorst, H. 1990 Die Rattangärten der DayakBenuaq in Ost Kalimantan. M.A. Thesis, University of Göttingen, Germany.

Latief, H. 1996/97 Upacara Adat Kwangkay. Departemen Pendidikan dan Kebudayaan, Direktorat Jendral Kebudayaan, Jakarta, Indonesia.

Latief, H. 1998 Belian: Tari Penyembuhan di Kalimantan Timur. Yayasan CRA, Balikpapan, Indonesia.

Lewis, O. 1971 La Vida: Eine puertoricanische Familie in der Kultur der Armut. San Juan \& New York. Econ Verlag, Düsseldrof.

Lewis, O.1996 The culture of poverty. In: Gmelch, G. and Zenner, W.P. Urban Life. Readings in the Anthropology of the City. Waveland Press, Prospect Heights, Illinois. 
Madrah, D. 1997 Lemu: Ilmu Magis Suku Dayak Benuaq dan Tunjung. Puspa Swara, Jakarta.

Madrah, D. 2001 Adat Sukat Dayak Benuaq dan Tonyooi. Pusps Swara dan Yayasan Rio Tinto, Jakarta.

Madrah, D. and Karaakng 1997 Tempuutn: Mitos Dayak Benuaq dan Tunjung. Puspa Swara, Jakarta.

Massing, A. 1981 The journey to paradise: funerary rites of the Benuaq of East Kalimantan. Borneo Research Bulletin 13: 85-104.

Massing, A. 1982 Where medicine fails: Belian disease prevention and curing rituals among the Lawangan Dayak of East Kalimantan. Tribus 32: 85-105.

Massing, A. 1986 The Central Mahakam Basin in East Kalimantan: a socio-economic survey. Borneo Research Bulletin 18(1): 64-99.

Matius, P. 2004 Plant Diversity and Utilisation of Rattan Gardens: A Construction to Participatory Biodiversity Conservation within the Benuaq and Tunjing Tribe in East Kalimantan, Indonesia. Deutsche Gesellschaft für Technische Zusammenarbeit (GTZ), Eschborn.

Nanang, M. 1990. Alam Pikiran Dayak Benuaq di Desa Engkuni-Pasek, Kecamatan Barong Tongkok, Kabupaten Kutai: Studi Antropologis Dalam Ranga Peletakan Dasar Empiris Pembangunan Partisipatip. Proyek Operasi dan Perawatan Fasilitas Perguruan Tinggi, Universitas Mularwarman, Samarinda.

Narayan, D., Patel, R., Schafft, K., Rademacher, A. and Koch-Schulte, S. 2000a Voices of the Poor: Can Anyone Hear Us? World Bank, Washington, DC.

Narayan, D., Chambers, R., Shah, M.K. and Petesch, P. 2000b Voices of the Poor: Crying out for Change. World Bank, Washington, DC.

Nolen-Hoeksema, S. and Rusting, C.L. 1999 Gender differences in wellbeing. In: Kahneman, D., Diener, E. and Schwarz, N. (eds.) Wellbeing: The Foundations of Hedonic Psychology. Russell Sage Foundation, New York.

Oley, L. 1997 'Ulap Doyo': A study of Benuaq Dayak textiles in East Kalimantan. Borneo Research Bulletin 28: 155-156.

Organisation for Economic Co-operation and Development (OECD) 2001 The Development Assistance Committee Guidelines: Poverty Reduction. OECD, Paris.

Padoch, C. and Peluso, N.L. 1996 Borneo in Transition: People, Forests, Concervation and Development. Oxford University Press, Oxford.

Rhee, S. 2000 De facto decentralisation during a period of transition in East Kalimantan. AsiaPacific Community Forestry Newsletter 13(2): 34-40.

Ribot, J. 2002 Democratic Decentralisation of Natural Resources: Institutionalising Popular Participation. World Resources Institute, Washington, DC.

Safitri, M. and Bosko, R.E. 2002 Indigenous Peoples/ Ethnic Minorities and Poverty Reduction in Indonessia. Environment and Social Safeguard Devision, Asian Development Bank, Manila.

Sakai, M. 2002 Solusi Sengketa Tanah di Era Reformasi Politik dan Desentralisasi Indonesia: Kasus dari Sumatera Selatan. Jurnal Antropologi Indonesia 68: 40-56.

Sardjono, M.A. 1990 Die Lembo-Kultur in Ost-Kalimantan: ein Modell für die Entwicklung agroforstlicher Landnutzung in den Feuchttropen. Dissertation, Universität Hamburg.

Sardjono, M.A. and Samsoedin, I. 2001 Traditional knowledge and practice of biodiversity conservation: the Benuaq Dayak community of East Kalimantan. In: Colfer, C.J.P. and Byron, Y. (eds.) People Managing Forests: The Link between Human Well Being and Sustainability. Resources for the Future, Washington and CIFOR, Bogor.

Scheper-Hughes, N. 1992 Death without Weeping. The Violence of Everyday Life in Brazil. University of California Press, Berkeley.

Scoones, I. 1998 Sustainable Rural Livelihoods: A Framework for Analysis, Working Paper 72. Institute for Development Studies, Brighton, UK.

Scott, J.C. 1985 Weapons of the Weak: Everyday Forms of Peasant Resistance. Yale University Press (USB), New Haven.

Sen, A. 1993 Capability and well-being. In: Nussbaum, M.C. and Sen, A.K. (eds.) The Quality of Life. Clarendon Press, Oxford.

Sen, A.K. 1997 Editorial: Human capital and human capability. World Development 25(12): 1959-1961.

Sen, A.K. 1999 Development as Freedom. Oxford University Press, Oxford.

Shackleton, S., Campbell, B., Wollenberg, E. and Edmunds, D.2002 Devolution and Communitybased Natural Resource Management: Creating 
Space for Local Peopleto Participate and Benefit? Natural Resource Perspectives No. 76. ODI, London.

Sillander, K. 1995 Local identity and regional variation: notes on the lack of significance of ethnicity among the Luangan and the Bentian. Borneo Research Bulletin 26: 69-95.

Solesbury, W. and Daniels, D. 2002 The Sustainable Livelihoods Approach: Tracing the Influence of Research on Policy and Practice. Department for International Development, London.

Susser, I. 1996 The construction of poverty and homelessness in US cities. Annual Review of Anthropology 25: 411-435.

Sumner, A. 2004 Economic Wellbeing and Noneconomic Wellbeing: A Review of the Meaning and Measurement of Poverty. WIDER Research Paper No. 2004/30.

Sumner, A. 2007 Meaning versus measurement: why do 'economic' indicators of poverty still predominate? Development in Practice 17(1): 4-13.

Thomi, W., Steinich, M. and Polte, W. (eds.) 2001 Dezentralisierung in Entwicklungsländern. Jüngere Ursachen, Ergebnisse und
Perspektiven staatlicher Reformpolitik. Nomos Verlagsgesellschaft, Baden-Baden.

United Nations (UN) 2000 Millennium Declaration. United Nations, Geneva.

Venz, O. 2002 Das Menschenbild, der Tod und das Jenseits bei den Benuaq-Dayak in OstKalimantan. Master's Thesis, Freie Universität, Berlin, Germany.

Verne, M. 2005 Der Mangel an Mitteln: Konsum, Kultur und Knappheit in einem Hausadorf im Niger. Dissertation, University of Bayreuth, Germany.

Weinstock, J.A. 1983 Kaharingan and the Luangan Dayaks: Religion and Identity in Central-East Borneo. Ph.D. Dissertation, Cornell University, Ithaca, USA.

Wikan, U. 1980 Life Among the Poor in Cairo. Tavistock, London.

Wikan, U. 1996 Tomorrow, God Willing: Selfmade Destinies in Cairo. Chicago University Press, Chicago.

World Bank 2000 World Development Report 2000/1: Attacking Poverty. World Bank, Washington, DC. 
CIFOR is a leading international forestry research organisation established in 1993 in response to global concerns about the social, environmental, and economic consequences of forest loss and degradation. CIFOR is dedicated to developing policies and technologies for sustainable use and management of forests, and for enhancing the well-being of people in developing countries who rely on tropical forests for their livelihoods. CIFOR is one of the 15 centres of the Consultative Group on International Agricultural Research (CGIAR). With headquarters in Bogor, Indonesia, CIFOR has offices in Brazil, Bolivia, Burkina Faso, Cameroon, Ethiopia, India, Zambia and Zimbabwe, and it works in over 30 other countries around the world.

\section{Donors}

CIFOR receives its major funding from governments, international organizations, private foundations and regional organizations. In 2006, CIFOR received financial support from Australia, Asian Development Bank (ADB), African Wildlife Foundation, Belgium, Canada, Carrefour, Cecoforma, China, Centre de coopération internationale en recherche agronomique pour le développement (CIRAD), Convention on Biological Diversity, Cordaid, Conservation International Foundation (CIF), European Commission, Finland, Food and Agriculture Organization of the United Nations (FAO), Ford Foundation, France, German Agency for Technical Cooperation (GTZ), German Federal Ministry for Economic Cooperation and Development (BMZ), German Foundation for International Cooperation, Global Forest Watch, Indonesia, Innovative Resource Management (IRM), International Institute for Environment and Development, International Development Research Centre (IDRC), International Fund for Agricultural Development (IFAD), International Tropical Timber Organization (ITTO), Israel, Italy, the World Conservation Union (IUCN), Japan, Korea, MacArthur Foundation, Netherlands, Norway, Netherlands Development Organization, Overseas Development Institute (ODI), Peruvian Secretariat for International Cooperation (RSCI), Philippines, Spain, Sweden, Swedish University of Agricultural Sciences (SLU), Switzerland, The Overbrook Foundation, The Tinker Foundation Incorporated, The Nature Conservancy (TNC), Tropical Forest Foundation, Tropenbos International, United States, United Kingdom, United Nations Environment Programme (UNEP), United Nations Educational, Scientific and Cultural Organization (UNESCO), United Nations Forum on Forests (UNFF), Wageningen International, World Bank, World Resources Institute (WRI) and World Wide Fund for Nature (WWF). 


\section{Poverty and Decentralisation in Kutai Barat: The Impacts of Regional Autonomy on Dayak Benuaq Wellbeing}

This research report summarises the findings of a field research which was carried out in Kutai Barat, East Kalimantan, Indonesia as an integral part of the CIFOR-BMZ project Making Local Government More Responsive to the Poor: Developing Indicators and Tools to Support Sustainable Livelihood under Decentralization.

The report shows the impacts regional autonomy had on the wellbeing of the Dayak Benuaq, a forest-dependent, major population group of Kutai Barat. It provides insights into the Dayak Benuaq's own perceptions of poverty and wellbeing, documents changes following decentralisation, and explains the causal relations behind these ongoing processes and their intertwinement with regional autonomy.

This research report is published on the web in English and Indonesian in downloadable format (www.cifor.cgiar.org/publications).
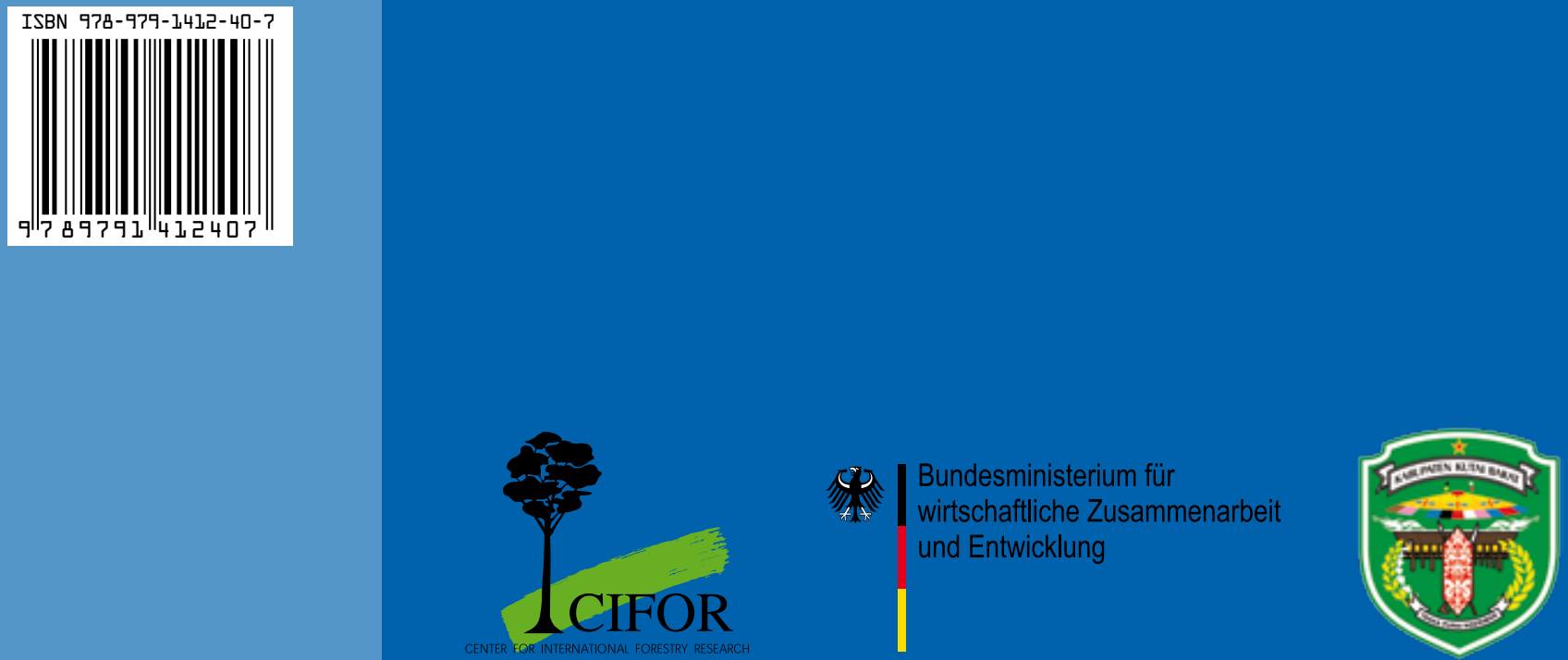